\title{
Inflammation and Nitro-Oxidative Stress in Current Suicidal Attempts and Current Suicidal Ideation: a Systematic Review and Meta-Analysis.
}

\section{Running title: immune activation in current suicidal behaviors}

Asara Vasupanrajit, M.Sc. ${ }^{a}$; Ketsupar Jirakran, M.Sc. ${ }^{\text {a,b }}$; Chavit Tunvirachaisakul, M.D., Ph.D. ${ }^{a}{ }^{\text {c }}$; Marco Solmi, M.D., Ph.D. ${ }^{\mathrm{f}, \mathrm{g}, \mathrm{h}}$, Michael Maes, M.D., Ph.D. ${ }^{\mathrm{a}, \mathrm{c}, \mathrm{d}, \mathrm{e}}$

${ }^{a}$ Department of Psychiatry, Faculty of Medicine, Chulalongkorn University, Bangkok, Thailand.

b Maximizing Thai Children's Developmental Potential Research Unit, Department of Pediatrics, Faculty of Medicine, Chulalongkorn University, Bangkok, Thailand.

${ }^{\mathrm{c}}$ Cognitive Impairment and Dementia Research Unit, Department of Psychiatry, Faculty of Medicine, Chulalongkorn University, Bangkok, Thailand.

d IMPACT Strategies Research Center, Deakin University, Geelong, Australia.

e Department of Psychiatry, Medical University of Plovdiv, Plovdiv, Bulgaria.

${ }^{\mathrm{f}}$ University of Ottawa, Psychiatry Department, Ottawa, Ontario, Canada

g The Ottawa Hospital, University of Ottawa, Ottawa, Ontario, Canada

h Ottawa Hospital Research Institute (OHRI), Clinical Epidemiology Program, University of Ottawa, Ottawa, Ontario, Canada

\section{Corresponding author:}

Prof. Dr. Michael Maes, M.D., Ph.D.

Department of Psychiatry, Faculty of Medicine, Chulalongkorn University, Bangkok, 10330

Thailand

Email: Dr.michaelmaes@ hotmail.com; asara.vasu@gmail.com 


\begin{abstract}
A meta-analysis showed a significant association between activated immune-inflammatory and nitro-oxidative (IO\&NS) pathways and suicide attempts (SA). There are no data whether suicidal ideation (SI) is accompanied by activated IO\&NS pathways and whether there are differences between SA and SI. The current study searched PubMed, Google Scholar, and Web of Science, for articles published from inception until May 10, 2021, and systematically reviewed and meta-analyzed the association between recent SA/SI ( $<3$ months) and IO\&NS biomarkers. We included studies which compared psychiatric patients with and without SA and SI and controls (either healthy controls or patients without SA or SI) and used meta-analysis (random-effect model with restricted maximum-likelihood) to delineate effect sizes with $95 \%$ confidence intervals (CI). Our search included 59 studies comprising 4.034 SA/SI cases and 12.377 controls. Patients with SA/SI showed activated IO\&NS pathways (SMD: 0.299; CI: 0.200; 0.397) when compared to controls. The immune profiles were more strongly associated with SA than with SI, particularly when compared to healthy controls, as evidenced by activated IO\&NS pathways (SMD: 0.796; CI: 0.503; 1.089), an immune-inflammatory response (SMD: 1.409; CI: 0.637; 1.462), inflammation (SMD: 1.200; CI: 0.584; 1.816), and neurotoxicity (SMD: 0.904; CI: 0.431; 1.378). The effects sizes of the IO\&NS, immune-inflammatory response and inflammatory profile were significantly greater in SA than in SI. In conclusion: increased neurotoxicity due to inflammation and nitrooxidative stress and lowered neuroprotection may explain at least in part why psychiatric patients show increased SA and SI. The IO\&NS pathways are more pronounced in recent SA than in SI.
\end{abstract}

Keywords: suicide, neuro-immune, inflammation, oxidative and nitrosative stress, depression, mood disorders, schizophrenia, psychiatry 


\section{Introduction}

Non-fatal suicide behaviors (SB) are self-injurious behaviors, which may be classified according to their severity into suicidal ideation (SI) and suicide attempts (SA) ${ }^{1}$. A study across 17 countries shows that SI has a greater lifetime prevalence than SA, namely $9.2 \%$ and $2.7 \%$, respectively ${ }^{2}$, indicating that not all individuals with SI will attempt suicide. Many different risk factors may lead to $\mathrm{SB}^{3,4}$ but psychiatric disorders are the major risk factors ${ }^{5,6}$. Individuals with major depressive disorder (MDD) show an almost eight-fold increased risk of suicide, whilst bipolar disorder (BD) and schizophrenia (SCZ) show a six-fold increased risk as compared with individuals without these psychiatric disorders ${ }^{6}$.

There is now evidence that activation of immune-inflammatory and nitro-oxidative (IO\&NS) pathways is involved in the pathophysiology of major psychiatric disorders, including $\mathrm{MDD}, \mathrm{BD}$, and $\mathrm{SCZ}^{7-10}$. These disorders are characterized by a simultaneous activation of the immune-inflammatory response system (IRS) and the compensatory immune-regulatory system (CIRS), which may down-regulate the IRS. Electronic Supplementary File (ESF) 1 Table 1 shows the IRS-CIRS pathways, and their features involved in those major psychiatric disoders. ${ }^{11-}$ 13. IRS activation is accompanied by the induction of nitro-oxidative (O\&NS) pathways with increased production of reactive oxygen (ROS) and nitrogen species (RNS) especially when the antioxidant defenses are reduced ${ }^{7}$. The consequent redox disbalance may cause increased damage to lipids, proteins, DNA, and mitochondria ${ }^{7}$. Moreover, many IO\&NS markers have neurotoxic effects, including interleukin (IL-)2, IL-6, tumor necrosis factor-alpha (TNF- $\alpha$ ), interferon-gamma (IFN- $\gamma$ ), some chemokines (i.e., CCL-2, CCL-5), C-reactive protein (CRP), quinolinic acid (QA), picolinic acid (PA), malondialdehyde (MDA), and nitric oxide metabolites (NOx) ${ }^{13,14}$. Increased neurotoxicity may cause dysfunctions in gray and white matter plasticity, which in turn are 
associated with affective disorders and $\mathrm{SCZ}^{13-15}$. In contrast, antioxidants, including albumin, vitamin-D, and high-density lipoprotein (HDL), and neurotrophic substances, including brainderived neurotrophic factor $(\mathrm{BDNF})^{16}$, may have neuroprotective effects thereby protecting the central nervous system (CNS) against the neurotoxic effects of the IRS ${ }^{7}$.

Since the 1990ties, there were also studies implicating IO\&NS pathways in the pathophysiology of $\mathrm{SB}^{17,18}$. Since then, a rising number of studies have examined the relationship between SB (either SA or SI) and IO\&NS biomarkers, including IL-1 $\beta$, IL-6, TNF- $\alpha$, IFN- $\gamma$, chemokines such as IL-8, and the neutrophil-to-lymphocyte ratio; CIRS markers including IL-4, IL-10, and soluble IL-2 receptor (sIL-2R); acute phase response (APR) productions such as CRP and albumin; O\&NS markers (i.e., MDA, NOx); and antioxidants or neurotrophic factors including albumin, BDNF, omega-3 polyunsaturated fatty acids (PUFAs), HDL-cholesterol, total antioxidant capacity (TAC), and vitamin D $3^{19,23,24}$. One of the most consistently reported abnormalities in SB is the increase in IL-6 in cerebrospinal fluid (CSF), blood, and postmortem brain, whilst more controversial findings were observed for other pro-inflammatory cytokines ${ }^{20}$, ${ }^{21}$. It is noteworthy that the cytokine imbalance in SB may present with activation of the tryptophan catabolite (TRYCAT) pathway leading to lowered levels of tryptophan (TRP) and increased levels of TRYCATs including QA, PA, and kynurenine $(\mathrm{KYN})^{4,22,23 .}$

Meta-analyses, which examined associations with cytokines other than IL-6, frequently reported controversial findings. For example, Black and Miller $^{24}$ found significantly increased blood levels of IL-1 $\beta$, whereas Ducasse et al. ${ }^{25}$ reported a medium effect size with lower IL-2 and IL-4 but higher TGF- $\beta$ plasma levels. CRP (positively) 26,27 and BDNF (negatively) ${ }^{28}$ were significantly associated with $\mathrm{SB}$, while $\mathrm{SB}$ was associated with BDNF in plasma ${ }^{28}$ but not in $\operatorname{serum}^{28,29}$. 
Importantly, most previous meta-analyses on IO\&NS blood biomarkers and suicide examined SA and SI patients lumped together in one SB group without considering possible differences between these groups ${ }^{24-26}$. Hence, the current study aimed to systematically review and meta-analyze the association between IO\&NS blood biomarkers and recent SB and to delineate differences among SA and SI. The examination of solitary IO\&NS biomarkers is less relevant because these compounds take part in highly connected networks and subnetworks. In this regard, Maes et al. ${ }^{9,15}$ showed that the combination of several IO\&NS biomarkers into weighted composite scores may improve our understanding of the pathways involved in affective disorders, schizophrenia and SB. Therefore, we here examine whether SA and/or SI are associated with composite scores reflecting IO\&NS (the primary analyses) and its subdomains namely IRS, inflammation, neurotoxicity, and neuroprotection (the secondary analyses) as described in ESF1 Table 1 . In addition, we also examine solitary biomarkers such as CRP (part of the inflammation profile) and BDNF (part of neuroprotection profile). Based on previous knowledge, we hypothesized that a) in patients with SA and SI, IO\&NS, and IRS, inflammation, neurotoxicity, and CRP are increased, whereas neuroprotection and BDNF are reduced when compared with controls; and b) that aberrations in these functional profiles are more pronounced in SA than in SI.

\section{Materials and methods}

Our methodological approach was based on the guidelines of the Preferred Reporting Items for Systematic Reviews and Meta-Analyses (PRISMA) 2020 $0^{30}$, the Cochrane Handbook for Systematic Reviews and Interventions ${ }^{31}$, and the Meta-Analyses of Observational Studies in Epidemiology (MOOSE) ${ }^{32}$. We followed an a priori protocol which is available upon request from 
the last author. The draft or process of this study did not directly or indirectly involve public or patient representatives.

Scope of systematic review

This study classified SB into 2 groups, namely SA and $\mathrm{SI}^{1}$. We combined different biomarkers into composites according to their well-established functions (ESF 1 Table 1). This study first selected manuscripts, which were published in peer-reviewed journals, and then searched additional records in the reference lists of the studies and grey literature. We included English case-control studies or cohort studies when these included a control group and compared SB (SA+ or SI+ within 3 months before the study) with controls, including non-SB patients (SAor SI-) and/or healthy controls (HC), alone and together. As such, we also examined differences in effect sizes between SA+versus SA- and SI+ versus SI- within patients with psychiatric disorders. Moreover, we also examined possible differences in effect sizes between SA and SI. We reviewed papers, which included patients and controls of both sexes, all ages and ethnicities, and examined IO\&NS biomarkers in blood, serum, and plasma but not CSF, urine, platelets or stimulated whole blood.

We contacted the authors of eligible studies, which did not report mean and standard deviation $(\mathrm{SD})$ or standard error (SE) values and requested to provide means, $\mathrm{SD}$, and number of cases and controls. When the authors did not respond to our request, we computed mean and SD values using formulas published by Wan et al. ${ }^{33}$ for studies presenting median with either interquartile range (IQR) or minimum/maximum values. We excluded studies reporting animal models, translational and genetic research, or studies without controls. Any reasons why studies were excluded were recorded. 


\section{Literature search and data extraction}

A systematic review of studies was conducted using the electronic databases including PUBMED/MEDLINE, Google Scholar, and Web of Science from inception to 10th May 2021. The search used the major terms of IO\&NS biomarkers and suicide (ESF 1 Table 2), include “inflamm*” OR immun*”, “cytokine”, “chemokine”, "IL-6”, “IL-1”, “interleukin”, "C-Reactive Protein", “CRP”, “tumor necrosis factor", "TNF", “interferon”, "IFN”, "Transforming growth factor", "TGF", “Tryptophan", “Oxidative stress", "Antioxidants", “Zinc”, "Vitamin", “Albumin", "Nitric oxide", "Lipid hydroperoxides", “Omega 3", “Coenzyme Q10”, "DHA”, "suicid*". We conducted a manual search on the reference list of the studies included and previous meta-analysis studies.

The first author (AV) screened the eligibility manuscripts by considering the titles and abstracts and collected the full text of the potentially eligible papers and extracted the key data into a predefined Excel spread sheet. The second author $(\mathrm{KJ})$ independently checked the extracted data once the first author (AV) completed all information. In case of disagreement, the last author (MM) was consulted. We used a methodological quality and red-point score checklist, namely the immune cofounder's scale (ICS), adapted from Andrés-Rodríguez et al. ${ }^{34}$ and Vasupanrajit et al. ${ }^{19}$, which was slightly modified by the last author (ESF 1 Table 3).

\section{Statistical Analysis}

This study performed statistical analysis using the Comprehensive meta-analysis (CMA) V3 software. The precise methods were described previously. ${ }^{18}$ The primary outcome was the pooled standardized mean difference (SMD) of the IO\&NS profiles. The secondary outcomes were 
pooled SMD of the IO\&NS subdomains, namely IRS, inflammation, CRP, neurotoxicity, antioxidant/neuroprotective (ANTIOXPRO), and BDNF, which were examined to explore which components of the IO\&NS are more relevant to recent SA and SI. Hence, in the present MA, we employed synthetic scores which reflect outcome profiles and compared these scores between SA and SI and controls. For studies reporting more than one IO\&NS biomarker, a synthetic score was computed using the mean of the outcomes, while assuming dependence. We used a random effect model with restricted maximum-likelihood because there are differences in study design, measuring time, and participants' characteristics across studies. The random-effects subgroup meta-analysis were performed, comparing patient subgroups (either SA+ or SI+) versus controls. This study computed the SMD values with $95 \%$ confidence intervals (CI) and used an alpha level of 0.05 indicating statistically significant results (two sided tests). The Cochrane Q test and the $I^{2}$ metric were computed, but Tau $(\tau)$ and $\tau^{2}$ was used to evaluate heterogeneity ${ }^{35,36}$. If $\tau^{2}$ was imprecise, we investigated potential sources of heterogeneity across studies when at least 10 studies provided data of the same profile, using either subgroup meta-analysis (with minimum of three studies per sub-group) or random-effects meta-regression analyses (with minimum of ten studies).

Sensitivity analyses were performed to investigate the robustness of the pooled combined meta-analysis effects and between-study heterogeneity using the leave-one-out method. We used the classical fail-safe $\mathrm{N}$ method, Kendall tau with continuity correction (using one-tailed p-values) and Egger's regression intercept (using one tailed p-values) to evaluate small study effects including publication bias. We also used funnel plots, which display study precision on the y-axis and the SDM on the $\mathrm{x}$-axis, to detect small study effects or systemic heterogeneity by simultaneously displaying the observed studies and the imputed missing values. 


\section{Results}

Search results

Our search strategy identified 2451 reports. Of those, 64 articles ${ }^{17,18,20,37-97}$ were assessed in our systematic review after removing duplicated citations and using the selection criteria. We removed 5 articles $^{50,63,71,75,88}$ from the meta-analysis for reasons shown in the ESF 1 Table 5. Consequently, 59 articles $^{17,18,20,37-49,51-62,64-70,72-74,76-87, ~ 89-97 ~}$ were considered in the meta-analysis (Figure 1).

ESF 1 Table 4 shows the characteristics of the included studies. Fifty-two articles were case control studies, and four articles were cohort studies, two were retrospective, and one was a longitudinal study. Thirty-three studies assayed the biomarkers in serum, 18 in plasma, 4 in blood, and 4 reported mixed mediums. Of these, only 35 studies samples reported the specific time for blood sampling. The age range of all participants samples was $12-89$ years old. We included participants from all continents except Australasia, namely 1 study from Belgium, Croatia, Egypt, Iran, Ireland, Japan, Netherland, and Tunisia; 2 studies from Canada, France, India, Italy, Mexico, Poland, and Taiwan; 3 studies from Brazil and Iraq; 4 studies from Sweden; 6 studies from China and Turkey; 7 studies from USA; and 8 studies from South Korea. The median quality scores were $5.7(\min =1.6, \max =9.7)$, whereas the median red point score was $17.5(\min =9.0, \max =25.0)$.

The meta-analysis included 16.411 participants samples, namely 4.034 cases (either SA+ or SI+) and 12.377 controls. We used subgroups within the study as unit of analysis to compare 2.511 SA+ cases versus 7.784 SA- and heathy controls combined, and 1.523 SI+versus 4.593 SIand healthy controls combined (Table 1). 
We found that $42.05 \%$ of the SA patients in the 59 studies belonged to a mixed group of psychiatric disorders (MIX), whereas 34.41\% suffered from MDD, 19.59\% of affective disorders, and $1 \%$ showed other psychiatric disorders including schizophrenia and adjustment disorders (OTHER). We found that $23.7 \%$ of the SI+ cases suffered from MDD and $23.57 \%$ from affective disorders, whilst $23.05 \%$ and $9.26 \%$ of the cases were allocated to the MIX or OTHER class. Most $\mathrm{SA}+$ cases were included based on the attempted suicidal act $(67.98 \%)$ and the others were included based on a semi-structure interview (32.02\%), whereas most of SI+ cases were assessed by a self-report questionnaire $(63.23 \%)$ and the remaining using a semi-structured interview $(36.76 \%)$.

\section{Qualitative synthesis}

Table 1 shows the distribution of the SMD and confidence intervals of the outcome profiles. Inspecting the confidence intervals showed that most included studies favored SB and that only 1 or 2 studies reporting on IO\&NS, IRS, inflammation, neurotoxicity, and ANTIOXPRO showed confidence intervals which were entirely located on the negative side of zero. All studies on CRP and BDNF favored SB and no studies showed a CI, which was entirely on the negative side of zero. Furthermore, there were two studies, not included in the CMA (ESF 1 Table 5), which reported no significant findings on plasma cytokines ${ }^{63}$, chemokines $^{63}$, and $\mathrm{TRP}^{88}$, whereas the other three studies revealed inconsistent results on plasma CRP ${ }^{50,63,75}$. Regarding the SB subtypes SA and SI, we found that most studies favor SA and that no CI was entirely located on the negative side of zero (except the ANTIOXPRO profile), whereas in the SI studies 1 or 2 confidence intervals were entirely located on the negative side of zero. In addition, there were no significant findings 
on the plasma TRP/amino acid ratio $^{71}$ in studies which were not included in the CMA (ESF 1 Table 5) and which compared SA+ cases with SA- controls.

Meta-analysis of the primary outcome: IO\&NS profile

Table 2 and Figure 2 show that there is a significant difference in the overall pooled effect size of 0.299 when comparing IO\&NS in SB with controls. Since there is some heterogeneity, we used subgroup analysis within study as the unit of analysis and found that the comparison of SA+ versus controls yielded a SMD of 0.387, and SI+ versus controls a SMD of 0.167. When using the subgroups as the unit of analysis, we found that the comparison of SA+versus SA- yielded a SMD of 0.255 , whereas SA+versus $\mathrm{HC}$ yielded a large, pooled effect size of 0.796 . The comparison of SI+ versus SI- yielded a significantly but small effect size ( $\mathrm{n}=21$; SMD: 0.156; 95\%CI: 0.016; 0.296), whereas the SMD was not significantly different when comparing SI+ with HC. ESF 2 Figure 1 showed the differences in the effect sizes of the comparisons of SA+ vs controls $(\mathrm{SMD}=0.387)$ and $\mathrm{SI}+$ versus controls $(0.167)$ which was significant $\left(\chi^{2}=5.14, \mathrm{df}=1, \mathrm{p}=0.023\right)$, indicating that SA+ is more strongly associated with IO\&NS than SI+. Sensitivity analysis using the leave-one-out method did not alter the results of these meta-analysis (and any of the metaanalyses described below). Consequently, we performed a sensitivity analysis on the high-quality studies (quality score $\geq 7.0$; redpoint score $\leq 18.0$ ) and compared those with a low quality (quality score $\leq 4.0$; redpoint score>18.0). ESF 2 Figure 2 shows the meta-analysis performed on the 13 high-quality studies $44,46,52,53,55,64,66,69,70,72,84,91,93$ (SMD: $0.407 ; 95 \%$ CI: $0.203 ; 0.611 ; \tau^{2}=0.092$ ) and 5 low-quality studies $39,73,79,89,92$ (SMD: 0.129; 95\%CI: $0.014 ; 0.0 .243 ; \tau^{2}=0.005$ ) when comparing SB to controls. This difference between high- and low-quality studies was significant $\left(\chi^{2}=5.444, \mathrm{df}=1, \mathrm{p}=0.020\right)$. 
Meta-analyses of the secondary outcomes IRS profile

Table 2 reports a moderate, pooled effect size of 0.460 in overall SB cases. Subgroup analysis showed that the comparison of SA+versus controls yielded a significantly effect size of 0.590, whereas SI+ versus controls yielded a lower effect size of 0.231 . When using subgroups as the unit of analysis, we found that the comparison of SA+versus SA-yielded a SMD of 0.384, whereas SA+versus HC yielded a large, pooled effect size of 1.049. There was no significant difference between SI+ and SI- or HC groups. The difference in the effect sizes of the comparisons of $\mathrm{SA}+$ vs controls $(\mathrm{SMD}=0.590)$ and $\mathrm{SI}+$ versus controls $(0.231)$ was significant $\left(\chi^{2}=6.54, \mathrm{df}=1\right.$, $\mathrm{p}=0.011)$.

\section{Inflammatory profile}

We found that the inflammation score is higher in SB cases than in controls with a moderate effect size of 0.459. Subgroup analysis showed that the comparison of SA+versus controls yielded a SMD of 0.623, whereas the comparison of SI+ versus controls yielded a SMD of 0.239 (Figure 3). When using the subgroups as the unit of analysis, we found that the comparison of SA+versus SA- yielded a SMD of 0.414, whereas SA+versus HC yielded a large, pooled effect size of 1.200. There was no significant difference between SI+ and SI- or HC groups. The difference in the effect sizes of the comparisons of $\mathrm{SA}+$ vs controls $(\mathrm{SMD}=0.623)$ and $\mathrm{SI}+$ versus controls $(\mathrm{SMD}=0.239)$ was significant $\left(\chi^{2}=5.048, \mathrm{df}=1, \mathrm{p}=0.025\right)$. 
When comparing CRP in SB with controls, we found a pooled effect size of 0.573 (table 2). Subgroup analysis showed that the comparison of SA+versus controls yielded a significant pooled effect size of 0.689 , whereas SI+versus controls yielded a significant effect size of 0.429. When using subgroups as the unit of analysis, we found that the comparison of SA+versus SAyielded a SMD of 0.499, whereas SA+ versus HC yielded a large, pooled effect size of 1.311. The comparison of SI+ versus SI- yielded a significantly moderate effect size ( $\mathrm{n}=4$; SMD: 0.460 ; 95\%CI: $0.098 ; 0.822$ ). The comparison of SI+ versus HC showed only two studies and therefore we did not perform CMA. The difference in the effect sizes of the comparisons of SA+ vs controls and SI+ versus controls was not significant $\left(\chi^{2}=1.58, \mathrm{df}=1, \mathrm{p}=0.208\right)$.

\section{Neurotoxicity profiles}

Table 2 also shows that the neurotoxicity levels are significantly increased in SB as compared with controls with an overall pooled effect size of 0.403 . Subgroup analysis (with the subgroup as the unit of analysis) showed that the comparison of SA+versus controls yielded a significant pooled effect size of 0.524 , whereas SI+ versus controls yielded a lower effect size of 0.243. We found that the comparison of SA+versus SA- yielded a SMD of 0.403, whereas SA+ versus $\mathrm{HC}$ yielded a large, pooled effect size of 0.904 . There was no significant difference between SI+ and SI- or HC groups. The difference in the effect sizes of the comparisons of SA+ vs controls and SI+ versus controls was not significant $\left(\chi^{2}=3.61, \mathrm{df}=1, \mathrm{p}=0.057\right)$.

\section{ANTIOXPRO profiles}

We found significant associations between ANTIOXPRO scores in SB cases with a small, pooled effect size of 0.179 . The comparison of SA+versus controls yielded a low but significant 
effect size of 0.199 , whereas there were no significant differences when comparing SI+ and controls. When using the subgroups as the unit of analysis, we found that the comparison of SA+ versus SA- yielded a SMD of 0.137 , whereas SA+ versus $\mathrm{HC}$ yielded a SMD of 0.476 . The difference in the effect sizes of the comparisons of SA+ vs controls and SI+versus controls was not significant $\left(\chi^{2}=0.22, \mathrm{df}=1, \mathrm{p}=0.636\right)$.

BDNF

Table 2 shows that SB is accompanied by the lowered BDNF levels with a SMD of 0.479. The comparison of SA+versus controls yielded a SMD of 0.417 , and SI+ versus controls yielded a SMD of 0.665 . When using the subgroups as the unit of analysis, we found that the comparison of $\mathrm{SA}+$ versus $\mathrm{SA}$ - yielded a SMD of 0.256 , whereas $\mathrm{SA}+$ versus $\mathrm{HC}$ yielded a large, pooled effect size of 0.962 . The comparison of SI+ versus SI- yielded a significantly moderate effect size $(\mathrm{n}=3$; SMD: 0.587 ; 95\%CI: $0.324 ; 0.851)$. We are unable to perform the analyses of SI+ versus $\mathrm{HC}$ due to the small number of studies $(n=2)$. The difference in the effect sizes of the comparisons of SA+ vs controls and SI+ versus controls was not significant $\left(\chi^{2}=1.44, \mathrm{df}=1, \mathrm{p}=0.230\right)$.

\section{Other subgroup analyses and meta-regression analyses}

ESF 2 Table 1 shows the association among IO\&NS profiles and SB remained significant in patients with MDD and MIX, whereas in patients belonging to the affective and OTHER groups was not significant, and these differences were significant $\left(\chi^{2}=8.563 ; \mathrm{df}=3 ; \mathrm{p}=0.036\right)$. The IO\&NS markers showed a significant association with SB in inpatients but not in outpatients. The comparisons of in- and outpatients in SB versus controls $\left(\chi^{2}=8.147 ; \mathrm{df}=1 ; \mathrm{p}=0.004\right)$ and SA versus controls $\left(\chi^{2}=5.770 ; \mathrm{df}=1 ; \mathrm{p}=0.016\right)$ were significantly different. There were no significant 
differences in effect sizes obtained in studies using serum, plasma, and blood $\left(\chi^{2}=4.677 ; \mathrm{df}=2\right.$; $\mathrm{p}=0.096)$. There are significant associations between IO\&NS markers and SB in patients who are diagnosed based on the suicidal act or an interview, but not when the SB was assessed through self-report, and this difference was significant $(\chi 2=8.479 ; \mathrm{df}=2 ; \mathrm{p}=0.014)$. In SA, the IO\&NS effect size was significantly larger in studies which diagnosed SB by registering the act as compared with studies which used an interview $\left(\chi^{2}=7.102 ; \mathrm{df}=1 ; \mathrm{p}=0.008\right)$. In SI, there was no significant difference between interview and self-report $\left(\chi^{2}=0.015 ; \mathrm{df}=1 ; \mathrm{p}=0.902\right)$. Metaregression revealed no effects of latitude, quality scores, and redpoint scores.

\section{Publication bias}

ESF 2 Table 2 shows the impact of publication bias on the studies under the random-effect model. There is some degree of publication bias for IO\&NS, IRS, inflammation, CRP, neurotoxicity, and ANTIOXPRO studies with 6, 5, 3, 2, 4, and 4 missing studies samples on the right side of the funnel plot, respectively, and correction yielded an increase in the overall adjusted point estimate. There was no impact of publication bias on the BDNF studies.

\section{Discussion}

The first major finding of this systematic review and meta-analysis is that SB (namely SA and SI) is accompanied by significantly increased levels of the primary outcome variable, the IO\&NS profile, albeit with a small effect size. In addition, also the IRS, inflammation (including CRP), neurotoxicity, ANTIOXPRO (including BDNF) profiles were significantly associated with $\mathrm{SB}$, with small to moderate effect sizes. Our meta-analysis thus confirms that the pathophysiology of SB is related to activated IO\&NS pathways ${ }^{4,22,98}$ with elevated $\mathrm{CRP}^{26}$ and reduced BDNF 
levels. ${ }^{28}$ Most importantly, our results show that suicidal behaviors are associated with an inflammatory response which is mainly driven by M1 macrophage-derived cytokines ${ }^{11,} 99$ including IL-1 $\beta$, IL-6, and TNF- $\alpha$, which induce the production of acute phase proteins such as CRP and downregulate albumin, and by Th- 1 cells with increased production of IFN- $\gamma^{11}$. These products of activated macrophages and T cells exert neurotoxic effects thereby affecting white and gray matter plasticity ${ }^{11}$. Moreover, both M1 and Th-1 cytokines may stimulate indoleamine 2,3dioxygenase (IDO), thereby lowering plasma TRP and inhibiting 5-HT synthesis, and increasing the production of neurotoxic TRYCATs including KYN, and QA, which may result in N-MethylD-Aspartic acid (NMDA)-induced neurotoxicity ${ }^{8,99}$. Furthermore, increased indicants of nitrooxidative stress with increased lipid peroxidation and lowered antioxidant levels, further contribute to increased neurotoxicity and reduced neuroprotection. ${ }^{7}$ Chronically elevated IO\&NS pathways cause breakdown of the blood brain barrier (BBB), which allows neurotoxic molecules to enter the brain thereby contributing to the neurotoxic effects. Previously, it was shown that activated IO\&NS pathways are associated with major depressive and bipolar disorder, staging of affective disorders, neurodegenerative processes, and schizophrenia. ${ }^{11,99,100}$

We should stress that the present meta-analysis study used composite scores reflecting IO\&NS profiles. ${ }^{11,12,101}$ Previously, we have discussed the many advantages of using composite scores instead of solitary markers in case-control studies ${ }^{11,12,101}$ and in meta-analysis as well. ${ }^{18}$ For example, if a study would report on 2 inflammatory markers (e.g. CRP and albumin) with one being significantly associated with SA and the other not, it would mean that selecting only one biomarker in a meta-analysis may yield erroneous conclusions with regard to "inflammation"19. Therefore, performing meta-analyses on one biomarker only may not allow to generalize the findings because the results may by quite different after including all biomarkers of the same 
profile. Moreover, the selection of only one biomarker per study may induce more biological between-study variance because different confounding variables may differently affect the biomarkers of the same profile. ${ }^{19}$ For example, selecting CRP as an index of inflammation is prone to bias because CRP is affected by many confounding variables including early lifetime trauma, sex, age and especially body mass index ${ }^{19,102,103}$. In our study, the different biomarker scores were not only averaged in one and the same study but also averaged over all studies. As such, our metaanalyses used more robust synthetic indices of IO\&NS and its subdomains based on all available data and, therefore, these data allow to generalize the findings to the functional profiles specified in our study.

The second major finding of this study is that the effects sizes of the IO\&NS, IRS, inflammation, CRP, and neurotoxicity scores were higher in SA than in SI, and that the effect sizes of IO\&NS, IRS and inflammation were significantly greater in SA than in SI. These findings may indicate that IRS and inflammatory processes are more tightly associated with SA than with SI. This may point towards differences in the severity with SA being more severe than $\mathrm{SI}^{1}$. On the other hand, the effects sizes of the comparisons between SA and SI were not significant when considering CRP, neurotoxicity, ANTIOXPRO and BDNF. Therefore, the results of the current meta-analysis do not confirm the results of Gibbs et al. ${ }^{57}$ who reported significant differences in serum hs-CRP levels between SA and SI. All in all, these results show that the higher IO\&NS and IRS profiles in SA versus SI should be attributed to smaller but cumulative effects of inflammation, neurotoxicity, and lowered neuroprotection in SA.

The study showed some statistical heterogeneity as assessed using the tau $(\tau)$ statistic, which represents a precise measurement of heterogeneity and which is insensitive to the number of patients or studies in the meta-analysis. ${ }^{35,36}$ On the other hand, Q-values and the $I^{2}$ metric do 
not reflect the degree of heterogeneity, although frequently employed as such. ${ }^{18}$ Nevertheless, the current meta-analysis was able to detect five possible sources of statistical heterogeneity. Firstly, differences in outpatient versus inpatient status with higher effect sizes in the latter. This may be explained by effects of severity of illness which is higher in inpatients than outpatients ${ }^{104}$, and the higher frequency of SA in inpatients ${ }^{104}$. The second source of heterogeneity concerns the assessment of SB with a greater effect size when the diagnosis of SA was based on the suicidal act rather than on an interview. These results show that the assessment of SB based on interview and self-report may largely underestimate the actual effect sizes and, therefore, are inaccurate assessment methods. Future research on SB should recruit patients with SA based on the registered suicidal act.

Thirdly, the quality of the included papers contributed to heterogeneity as evidenced by higher pooled effect sizes of IO\&NS in high-quality studies than low-quality studies. The fourth source of statistical heterogeneity is due to the choice of controls, namely patients without SB versus heathy controls. As such we found that that the pooled effect sizes of the IO\&NS, IRS, inflammation (including), CRP, and neurotoxicity profiles were larger when comparing SB with healthy controls as reference group (between 0.796 and 1.311), whereas lower effect sizes were obtained when comparing patients with and without SB (between 0.3 to 0.5 ). The comparisons with normal controls show that activated IO\&NS pathways are strongly associated with SA in patients with psychiatric disorders, and the comparisons obtained with patients without SB show that SB is accompanied by aberrations in IO\&NS pathways above and beyond the increased levels in psychiatric patients. Therefore, it is safe to conclude that activated IO\&NS, IRS, inflammatory and neurotoxic pathways and lowered neuroprotection are strongly associated not only with the major psychiatric disorders ${ }^{11,101}$ but also with the SB which are associated with those disorders. 
Fifthly, inspection of the forest plots shows that the heterogeneity is increased by a number of heterogeneity-influencing studies which favor SA. Previously, we performed sensitivity analyses on the included studies after deselecting a few heterogeneity-influencing studies and found that the prediction intervals no longer overlapped with the zero SMD but fell completely on the right site of zero. Indeed, a few small $\mathrm{n}$ studies that favor SA and show a very large effect size may bias SMD whereby the heterogeneity may increase in a random effect model and the latter may be more biased that when using a fixed effect model ${ }^{19}$. It should be added that there is probably nothing wrong with these heterogeneity-influencing studies, they only show a large SMD.

Several limitations should be considered when discussing our findings. Firstly, there are very few studies which assayed IL- $4^{56,72}$ and TGF- $\beta 1^{78}$ and therefore these important Th- 2 and T regulatory (Treg) cytokines could not be included in the CMA. Secondly, key biomarkers of other profiles were also missing. For example, haptoglobin, transferrin, and zinc were missing as inflammatory biomarkers (and its parent profiles). Vitamin E, coenzyme Q10, glutathione, catalase, MPO and xanthine oxidase were missing as O\&NS biomarkers. In fact, we were even unable to compute a CIRS profile, although most important to evaluate the homeostatic processes in the immune system. ${ }^{11}$ Therefore, future research should focus on the missing biomarkers, i.e., Treg cytokines such as IL-10 and TGF- $\beta 1$, Th-2 cytokines including IL-4, IL-5 and IL-13 (see also ESF Table 1; column "what is missing in SB research"). Thirdly, this study did not include other potential variables regarding severity of $\mathrm{SB}$, including lifetime $\mathrm{SB}^{19}$, staging of the major psychiatric disorders ${ }^{13}$, and stressful live events, including early lifetime trauma ${ }^{4}$. Further studies should also include those covariates.

In conclusion, this is the first meta-analysis to explore IO\&NS pathways in SA versus SI. Recent SB (within 3 months) is accompanied by aberrations in IO\&NS profiles, which are more 
strongly associated with SA than SI. Increased neurotoxicity due to inflammation and nitrooxidative stress may explain why psychiatric patients are at higher risk of SA and SI than healthy controls. As such, we have delineated new drug targets to treat SB, namely the IO\&NS subdomains.

\section{Declaration of Competing Interests}

The authors declare that they have no known competing financial interests or personal relationships that could have appeared to influence the work reported in this paper. MS received honoraria and has been a consultant for Angelini, Lundbeck.

\section{Ethical approval and consent to participate}

Not applicable.

\section{Consent for publication}

Not applicable.

\section{Availability of data and materials}

The dataset (CMA file) generated during and/or analyzed during the current study will be available from MM upon reasonable request and once the dataset has been fully exploited by the authors.

\section{Funding}


The study was funded by the $90^{\mathrm{TH}}$ Anniversary of Chulalongkorn University Scholarship (Grant Batch\#47 No. 3/2020).

\section{Author's contributions}

All authors contributed to the writing up of the paper. The work was designed by MM and AV. Data were collected by AV and KJ. Statistical analyses were performed by MM and AV. All authors revised and approved the final draft.

\section{Acknowledgements}

Not applicable.

\section{Compliance with Ethical Standards/Disclosure of potential conflicts of interest}

The authors have no conflicts of interest to declare that are relevant to the content of this article.

\section{Research involving Human Participants and/or Animals}

Not applicable.

\section{Informed consent}

Not applicable.

\section{References}


1. Posner K, Oquendo MA, Gould M, Stanley B, Davies M. Columbia Classification Algorithm of Suicide Assessment (C-CASA): classification of suicidal events in the FDA's pediatric suicidal risk analysis of antidepressants. The American journal of psychiatry 2007; 164(7): 1035-1043.

2. Nock MK, Borges G, Bromet EJ, Alonso J, Angermeyer M, Beautrais A et al. Cross-national prevalence and risk factors for suicidal ideation, plans and attempts. The British journal of psychiatry : the journal of mental science 2008; 192(2): 98-105.

3. Franklin JC, Ribeiro JD, Fox KR, Bentley KH, Kleiman EM, Huang X et al. Risk factors for suicidal thoughts and behaviors: A meta-analysis of 50 years of research. Psychol Bull 2017; 143(2): 187232.

4. Capuzzi E, Caldiroli A, Capellazzi M, Tagliabue I, Buoli M, Clerici M. Biomarkers of suicidal behaviors: A comprehensive critical review. Adv Clin Chem 2020; 96: 179-216.

5. Bachmann S. Epidemiology of Suicide and the Psychiatric Perspective. International journal of environmental research and public health 2018; 15(7): 1425.

6. Moitra M, Santomauro D, Degenhardt L, Collins PY, Whiteford H, Vos T et al. Estimating the risk of suicide associated with mental disorders: A systematic review and meta-regression analysis. $J$ Psychiatr Res 2021; 137: 242-249.

7. Maes M, Galecki P, Chang YS, Berk M. A review on the oxidative and nitrosative stress (O\&NS) pathways in major depression and their possible contribution to the (neuro)degenerative processes in that illness. Prog Neuropsychopharmacol Biol Psychiatry 2011; 35(3): 676-692.

8. Martin-Subero M, Anderson G, Kanchanatawan B, Berk M, Maes M. Comorbidity between depression and inflammatory bowel disease explained by immune-inflammatory, oxidative, and nitrosative stress; tryptophan catabolite; and gut-brain pathways. CNS Spectr 2016; 21(2): 184198.

9. Maes M, Sirivichayakul S, Matsumoto AK, Michelin AP, de Oliveira Semeão L, de Lima Pedrão JV et al. Lowered Antioxidant Defenses and Increased Oxidative Toxicity Are Hallmarks of Deficit Schizophrenia: a Nomothetic Network Psychiatry Approach. Mol Neurobiol 2020; 57(11): 45784597.

10. Solmi M, Suresh Sharma M, Osimo EF, Fornaro M, Bortolato B, Croatto G et al. Peripheral levels of $C$-reactive protein, tumor necrosis factor- $\alpha$, interleukin- 6 , and interleukin- $1 \beta$ across the mood spectrum in bipolar disorder: A meta-analysis of mean differences and variability. Brain Behav Immun 2021. 
11. Maes M, Carvalho AF. The Compensatory Immune-Regulatory Reflex System (CIRS) in Depression and Bipolar Disorder. Mol Neurobiol 2018; 55(12): 8885-8903.

12. Roomruangwong C, Noto C, Kanchanatawan B, Anderson G, Kubera M, Carvalho AF et al. The Role of Aberrations in the Immune-Inflammatory Response System (IRS) and the Compensatory Immune-Regulatory Reflex System (CIRS) in Different Phenotypes of Schizophrenia: the IRS-CIRS Theory of Schizophrenia. Mol Neurobiol 2020; 57(2): 778-797.

13. Maes M, Moraes JB, Bonifacio KL, Barbosa DS, Vargas HO, Michelin AP et al. Towards a new model and classification of mood disorders based on risk resilience, neuro-affective toxicity, staging, and phenome features using the nomothetic network psychiatry approach. Metabolic brain disease 2021; 36(3): 509-521.

14. Maes M, Plaimas K, Suratanee A, Noto C, Kanchanatawan B. The Protein-Protein Interaction Network of First Episode Psychosis and Schizophrenia Reveals Possible Trigger Factors and New Drug Targets among Intracellular Signal Transduction Pathways and Neurotoxicity Processes. Preprints 2021; 2021070596.

15. Maes M, Landucci Bonifacio K, Morelli NR, Vargas HO, Barbosa DS, Carvalho AF et al. Major Differences in Neurooxidative and Neuronitrosative Stress Pathways Between Major Depressive Disorder and Types I and II Bipolar Disorder. Molecular Neurobiology 2019; 56(1): 141-156.

16. Valvassori SS, Arent CO, Steckert AV, Varela RB, Jornada LK, Tonin PT et al. Intracerebral Administration of BDNF Protects Rat Brain Against Oxidative Stress Induced by Ouabain in an Animal Model of Mania. Mol Neurobiol 2015; 52(1): 353-362.

17. Maes M, Vandewoude M, Schotte C, Martin M, Blockx P, Scharpe S et al. Hypothalamic-pituitaryadrenal and -thyroid axis dysfunctions and decrements in the availability of L-tryptophan as biological markers of suicidal ideation in major depressed females. Acta Psychiatr Scand 1989; 80(1): 13-17.

18. Nässberger L, Träskman-Bendz L. Increased soluble interleukin-2 receptor concentrations in suicide attempters. Acta Psychiatr Scand 1993; 88(1): 48-52.

19. Vasupanrajit A, Jirakran K, Tunvirachaisakul C, Maes M. Suicide attempts are associated with activated immune-inflammatory, nitro-oxidative, and neurotoxic pathways: A systematic review and meta-analysis. Journal of Affective Disorders 2021; 295: 80-92.

20. Ganança L, Oquendo MA, Tyrka AR, Cisneros-Trujillo S, Mann JJ, Sublette ME. The role of cytokines in the pathophysiology of suicidal behavior. Psychoneuroendocrinology 2016; 63: 296-310. 
21. Serafini G, Parisi VM, Aguglia A, Amerio A, Sampogna G, Fiorillo A et al. A Specific Inflammatory Profile Underlying Suicide Risk? Systematic Review of the Main Literature Findings. Int J Environ Res Public Health 2020; 17(7).

22. Brundin L, Erhardt S, Bryleva EY, Achtyes ED, Postolache TT. The role of inflammation in suicidal behaviour. 2015; 132(3): 192-203.

23. Courtet $P$, Giner $L$, Seneque $M$, Guillaume $S$, Olie E, Ducasse D. Neuroinflammation in suicide: Toward a comprehensive model. World J Biol Psychiatry 2016; 17(8): 564-586.

24. Black C, Miller BJ. Meta-Analysis of Cytokines and Chemokines in Suicidality: Distinguishing Suicidal Versus Nonsuicidal Patients. Biol Psychiatry 2015; 78(1): 28-37.

25. Ducasse $D$, Olié $E$, Guillaume $S$, Artéro $S$, Courtet $P$. A meta-analysis of cytokines in suicidal behavior. Brain Behav Immun 2015; 46: 203-211.

26. Chen X, Pu J, Liu Y, Tian L, Chen Y, Gui S et al. Increased C-reactive protein concentrations were associated with suicidal behavior in patients with depressive disorders: a meta-analysis. Psychiatry Research 2020; 292: 113320.

27. Miola A, Dal Porto V, Tadmor T, Croatto G, Scocco P, Manchia M et al. Increased C-reactive protein concentration and suicidal behavior in people with psychiatric disorders: A systematic review and meta-analysis. Acta psychiatrica Scandinavica 2021.

28. Salas-Magaña M, Tovilla-Zárate CA, González-Castro TB, Juárez-Rojop IE, López-Narváez ML, Rodríguez-Pérez JM et al. Decrease in brain-derived neurotrophic factor at plasma level but not in serum concentrations in suicide behavior: A systematic review and meta-analysis. Brain Behav 2017; 7(6): e00706.

29. Eisen RB, Perera S, Banfield L, Anglin R, Minuzzi L, Samaan Z. Association between BDNF levels and suicidal behaviour: a systematic review and meta-analysis. Syst Rev 2015; 4: 187.

30. Page MJ, McKenzie JE, Bossuyt PM, Boutron I, Hoffmann TC, Mulrow CD et al. The PRISMA 2020 statement: an updated guideline for reporting systematic reviews. BMJ 2021; 372: $\mathrm{n71}$.

31. Higgins JPT, Thomas J, Chandler J, Cumpston M, Li T, Page MJ et al. Cochrane Handbook for Systematic Reviews of Interventions. Chichester (UK): John Wiley \& Sons, 2019.

32. Stroup DF, Berlin JA, Morton SC, Olkin I, Williamson GD, Rennie D et al. Meta-analysis of observational studies in epidemiology: a proposal for reporting. 2000; 283(15): 2008-2012. 
33. Wan X, Wang W, Liu J, Tong T. Estimating the sample mean and standard deviation from the sample size, median, range and/or interquartile range. BMC Medical Research Methodology 2014; 14(1): 135 .

34. Andrés-Rodríguez L, Borràs X, Feliu-Soler A, Pérez-Aranda A, Angarita-Osorio N, Moreno-Peral P et al. Peripheral immune aberrations in fibromyalgia: A systematic review, meta-analysis and meta-regression. Brain, Behavior, and Immunity 2020; 87: 881-889.

35. Borenstein M, Higgins JP, Hedges LV, Rothstein HR. Basics of meta-analysis: I(2) is not an absolute measure of heterogeneity. Res Synth Methods 2017; 8(1): 5-18.

36. Rücker G, Schwarzer G, Carpenter JR, Schumacher M. Undue reliance on I(2) in assessing heterogeneity may mislead. BMC Med Res Methodol 2008; 8: 79.

37. Aguglia A, Solano P, Giacomini G, Caprino M, Conigliaro C, Romano M et al. The Association Between Dyslipidemia and Lethality of Suicide Attempts: A Case-Control Study. 2019; 10(70).

38. Ai M, Wang J, Chen J, Wang W, Xu X, Gan Y et al. Plasma brain-derived neurotrophic factor (BDNF) concentration and the BDNF Val66Met polymorphism in suicide: a prospective study in patients with depressive disorder. Pharmgenomics Pers Med 2019; 12: 97-106.

39. Ainiyet B, Rybakowski JK. Suicidal behaviour and lipid levels in unipolar and bipolar depression. Acta Neuropsychiatr 2014; 26(5): 315-320.

40. Al-Amarei HM, Rasheed SMH, Eidan A. C-reactive Protein and its Relationship with Lipid Profile in Suicidal and Non Suicidal Adults with Major Depression. Indian Journal of Public Health Research \& Development 2019; 10(7): 569.

41. Almeida-Montes LG, Valles-Sanchez V, Moreno-Aguilar J, Chavez-Balderas RA, García-Marín JA, Cortés Sotres JF et al. Relation of serum cholesterol, lipid, serotonin and tryptophan levels to severity of depression and to suicide attempts. J Psychiatry Neurosci 2000; 25(4): 371-377.

42. Atik D, Cander B, Doğan S, Bulut B, Yazıcı R, Taşlıdere B. Relationship between suicidal patients and vitamin D: A prospective case-control study. Journal of Surgery and Medicine 2020; 4(9): 766770.

43. Baek JH, Kang ES, Fava M, Mischoulon D, Nierenberg AA, Yu BH et al. Serum lipids, recent suicide attempt and recent suicide status in patients with major depressive disorder. Prog Neuropsychopharmacol Biol Psychiatry 2014; 51: 113-118. 
44. Bradley KA, Case JA, Khan O, Ricart T, Hanna A, Alonso CM et al. The role of the kynurenine pathway in suicidality in adolescent major depressive disorder. Psychiatry Res 2015; 227(2-3): 206-212.

45. Brundin L, Sellgren CM, Lim CK, Grit J, Pålsson E, Landén M et al. An enzyme in the kynurenine pathway that governs vulnerability to suicidal behavior by regulating excitotoxicity and neuroinflammation. Transl Psychiatry 2016; 6(8): e865.

46. Chang CC, Tzeng NS, Kao YC, Yeh CB, Chang HA. The relationships of current suicidal ideation with inflammatory markers and heart rate variability in unmedicated patients with major depressive disorder. Psychiatry Res 2017; 258: 449-456.

47. Choi KW, Jang EH, Kim AY, Kim H, Park MJ, Byun S et al. Predictive inflammatory biomarkers for change in suicidal ideation in major depressive disorder and panic disorder: A 12-week follow-up study. J Psychiatr Res 2021; 133: 73-81.

48. De Berardis D, Serroni N, Marini S, Rapini G, Carano A, Valchera A et al. Alexithymia, suicidal ideation, and serum lipid levels among drug-naïve outpatients with obsessive-compulsive disorder. Braz J Psychiatry 2014; 36(2): 125-130.

49. Deveci A, Aydemir O, Taskin O, Taneli F, Esen-Danaci A. Serum BDNF levels in suicide attempters related to psychosocial stressors: a comparative study with depression. Neuropsychobiology 2007; 56(2-3): 93-97.

50. Dickerson F, Adamos M, Katsafanas E, Khushalani S, Origoni A, Savage C et al. The association between immune markers and recent suicide attempts in patients with serious mental illness: $A$ pilot study. Psychiatry Res 2017; 255: 8-12.

51. Dolsen MR, Prather AA, Lamers F, Penninx B. Suicidal ideation and suicide attempts: associations with sleep duration, insomnia, and inflammation. Psychol Med 2020: 1-10.

52. Eidan A, Al-Harmoosh R, Al-Amarei H. Estimation of IL-6, INFY, and Lipid Profile in Suicidal and Nonsuicidal Adults with Major Depressive Disorder. J Interferon Cytokine Res 2019; 39(3): 181189.

53. Ekinci O, Ekinci A. The connections among suicidal behavior, lipid profile and low-grade inflammation in patients with major depressive disorder: a specific relationship with the neutrophil-to-lymphocyte ratio. Nord J Psychiatry 2017; 71(8): 574-580.

54. Eisen RB, Perera S, Bawor M, Dennis BB, El-Sheikh W, DeJesus J et al. Exploring the Association between Serum BDNF and Attempted Suicide. Scientific Reports 2016; 6(1): 25229. 
55. Fang $\mathrm{X}$, Chen $\mathrm{Y}$, Wang $\mathrm{Y}$, Zhang $\mathrm{C}$. Identification of risk factors for suicidal ideation in patients with schizophrenia. Psychiatry Res 2019; 271: 195-199.

56. Gabbay V, Klein RG, Guttman LE, Babb JS, Alonso CM, Nishawala M et al. A preliminary study of cytokines in suicidal and nonsuicidal adolescents with major depression. J Child Adolesc Psychopharmacol 2009; 19(4): 423-430.

57. Gibbs HM, Davis L, Han X, Clothier J, Eads LA, Cáceda R. Association between C-reactive protein and suicidal behavior in an adult inpatient population. J Psychiatr Res 2016; 79: 28-33.

58. da Graça Cantarelli M, Nardin P, Buffon A, Eidt MC, Antônio Godoy L, Fernandes BS et al. Serum triglycerides, but not cholesterol or leptin, are decreased in suicide attempters with mood disorders. J Affect Disord 2015; 172: 403-409.

59. Grassi-Oliveira R, Brieztke E, Teixeira A, Pezzi JC, Zanini M, Lopes RP et al. Peripheral chemokine levels in women with recurrent major depression with suicidal ideation. Braz J Psychiatry 2012; 34(1): 71-75.

60. Grudet C, Malm J, Westrin A, Brundin L. Suicidal patients are deficient in vitamin D, associated with a pro-inflammatory status in the blood. Psychoneuroendocrinology 2014; 50: 210-219.

61. Gundogdu Meydaneri G, Meydaneri S. Can Neutrophil Lymphocyte Ratio Predict the Likelihood of Suicide in Patients with Major Depression? Cureus 2018; 10(4): e2510.

62. Janelidze S, Suchankova P, Ekman A, Erhardt S, Sellgren C, Samuelsson M et al. Low IL-8 is associated with anxiety in suicidal patients: genetic variation and decreased protein levels. Acta Psychiatr Scand 2015; 131(4): 269-278.

63. Jha MK, Cai L, Minhajuddin A, Fatt CC, Furman JL, Gadad BS et al. Dysfunctional adaptive immune response in adolescents and young adults with suicide behavior. Psychoneuroendocrinology 2020; 111: 104487.

64. Khan MS, Wu GWY, Reus VI, Hough CM, Lindqvist D, Westrin Å et al. Low serum brain-derived neurotrophic factor is associated with suicidal ideation in major depressive disorder. Psychiatry Res 2019; 273: 108-113.

65. Kim JM, Stewart R, Kang HJ, Jeong BO, Kim SY, Bae KY et al. Longitudinal associations between serum cholesterol levels and suicidal ideation in an older Korean population. J Affect Disord 2014; 152-154: 517-521. 
66. Kim YK, Paik JW, Lee SW, Yoon D, Han C, Lee BH. Increased plasma nitric oxide level associated with suicide attempt in depressive patients. Prog Neuropsychopharmacol Biol Psychiatry 2006; 30(6): 1091-1096.

67. Kim YK, Lee HP, Won SD, Park EY, Lee HY, Lee BH et al. Low plasma BDNF is associated with suicidal behavior in major depression. Prog Neuropsychopharmacol Biol Psychiatry 2007; 31(1): 78-85.

68. Kurosawa K, Terao T, Kanehisa M, Shiotsuki I, Ishii N, Takenaka R et al. Naturally absorbed polyunsaturated fatty acids, lithium, and suicide-related behaviors: A case-controlled study. J Affect Disord 2018; 241: 200-205.

69. Lee BH, Lee SW, Yoon D, Lee HJ, Yang JC, Shim SH et al. Increased plasma nitric oxide metabolites in suicide attempters. Neuropsychobiology 2006; 53(3): 127-132.

70. Lee BH, Kim H, Park SH, Kim YK. Decreased plasma BDNF level in depressive patients. J Affect Disord 2007; 101(1-3): 239-244.

71. Lauterbach E, Brunner J, Hawellek B, Lewitzka U, Ising M, Bondy B et al. Platelet 5-HT2A receptor binding and tryptophan availability in depression are not associated with recent history of suicide attempts but with personality traits characteristic for suicidal behavior. Journal of Affective Disorders 2006; 91(1): 57-62.

72. Liu MN, Tsai SJ, Yeh HL, Wu CC, Lin CP. MCP-2/CCL8 Level Associated With Suicidal Ideation in Elderly Men With Major Depression. Arch Suicide Res 2020; 24(3): 467-476.

73. Loas G, Dalleau E, Lecointe H, Yon V. Relationships between anhedonia, alexithymia, impulsivity, suicidal ideation, recent suicide attempt, C-reactive protein and serum lipid levels among 122 inpatients with mood or anxious disorders. Psychiatry Res 2016; 246: 296-302.

74. Ma YJ, Zhou YJ, Wang DF, Li Y, Wang DM, Liu TQ et al. Association of Lipid Profile and Suicide Attempts in a Large Sample of First Episode Drug-Naive Patients With Major Depressive Disorder. Front Psychiatry 2020; 11(953).

75. Melhem NM, Munroe S, Marsland A, Gray K, Brent D, Porta G et al. Blunted HPA axis activity prior to suicide attempt and increased inflammation in attempters. Psychoneuroendocrinology 2017; 77: 284-294.

76. Mensi R, Messaoud A, Mhallah A, Azizi I, Salah WH, Douki W et al. The association between altered lipid profile and suicide attempt among Tunisian patients with schizophrenia. Ann Gen Psychiatry 2016; 15: 36. 
77. Mohamed AE, El-Latif RRA, Youssef AM, Ibrahim AS. C-reactive protein and clinical subtypes of major depressive disorder at Zagazig University Hospitals. Middle East Current Psychiatry 2020; 27(1): 35 .

78. O'Donovan A, Rush G, Hoatam G, Hughes BM, McCrohan A, Kelleher C et al. Suicidal ideation is associated with elevated inflammation in patients with major depressive disorder. Depress Anxiety 2013; 30(4): 307-314.

79. Oh KY, Van Dam NT, Doucette JT, Murrough JW. Effects of chronic physical disease and systemic inflammation on suicide risk in patients with depression: a hospital-based case-control study. Psychol Med 2020; 50(1): 29-37.

80. Oshnokhah M, Bagheri M, Ghaneialvar H, Haghani K, Khorshidi A, Shahbazi A et al. OxidantAntioxidant Status in Suicide Behavior in Kurdish Ethnicity. Basic and Clinical Neuroscience 2020: $0-0$.

81. Ozer OA, Kutaniş R, Agargun MY, Beşiroğlu L, Bal AC, Selvi Y et al. Serum lipid levels, suicidality, and panic disorder. Compr Psychiatry 2004; 45(2): 95-98.

82. Park YM, Lee BH, Lee SH. The association between serum lipid levels, suicide ideation, and central serotonergic activity in patients with major depressive disorder. J Affect Disord 2014; 159: 62-65.

83. Pasyk S, Sanger N, Kapczinski F, Samaan Z. Evaluation of BDNF as a Biomarker for Impulsivity in a Psychiatric Population. Diagnostics (Basel) 2020; 10(6).

84. Peng R, Dai W, Li Y. Low serum free thyroxine level is correlated with lipid profile in depressive patients with suicide attempt. Psychiatry Res 2018; 266: 111-115.

85. Pinheiro RT, Pinheiro KA, da Cunha Coelho FM, de Ávila Quevedo L, Gazal M, da Silva RA et al. Brain-derived neurotrophic factor levels in women with postpartum affective disorder and suicidality. Neurochem Res 2012; 37(10): 2229-2234.

86. Priya PK, Rajappa M, Kattimani S, Mohanraj PS, Revathy G. Association of neurotrophins, inflammation and stress with suicide risk in young adults. Clin Chim Acta 2016; 457: 41-45.

87. Rasheed SMH, Eidan AJ, Al-dujaili AH, Abada LH, Al-Charrakh AH. Different cytokines and Lipid Profile in Suicidal and Non Suicidal Adults with Major depression. $J$ Annals of Tropical Medicine Health 2019; 22: 135-141.

88. Roggenbach J, Müller-Oerlinghausen B, Franke L, Uebelhack R, Blank S, Ahrens B. Peripheral serotonergic markers in acutely suicidal patients. 1. Comparison of serotonergic platelet measures 
between suicidal individuals, nonsuicidal patients with major depression and healthy subjects. Journal of Neural Transmission 2007; 114(4): 479-487.

89. Roy A, Roy M. No relationship between serum cholesterol and suicidal ideation and depression in African-American diabetics. Arch Suicide Res 2006; 10(1): 11-14.

90. Ruljancic N, Mihanovic M, Cepelak I, Bakliza A, Curkovic KD. Platelet serotonin and magnesium concentrations in suicidal and non-suicidal depressed patients. Magnes Res 2013; 26(1): 9-17.

91. Segoviano-Mendoza M, Cárdenas-de la Cruz M, Salas-Pacheco J, Vázquez-Alaniz F, La Llave-León $\mathrm{O}$, Castellanos-Juárez $\mathrm{F}$ et al. Hypocholesterolemia is an independent risk factor for depression disorder and suicide attempt in Northern Mexican population. BMC Psychiatry 2018; 18(1): 7.

92. Si YJ, Guo QW, Chen X, Yang M, Lin J, Fang DZ. Increased TG/HDL-C in female G allele carriers of rs1061622 at gene of tumour necrosis factor receptor 2 with suicidal ideation. Eur J Clin Invest 2020; 50(11): e13322.

93. Sowa-Kućma M, Styczeń K, Siwek M, Misztak P, Nowak RJ, Dudek D et al. Are there differences in lipid peroxidation and immune biomarkers between major depression and bipolar disorder: Effects of melancholia, atypical depression, severity of illness, episode number, suicidal ideation and prior suicide attempts. Progress in Neuro-Psychopharmacology and Biological Psychiatry 2018; 81: 372-383.

94. Su M, Li E, Tang C, Zhao Y, Liu R, Gao K. Comparison of blood lipid profile/thyroid function markers between unipolar and bipolar depressed patients and in depressed patients with anhedonia or suicidal thoughts. Mol Med 2019; 25(1): 51.

95. Velasco Á, Rodríguez-Revuelta J, Olié E, Abad I, Fernández-Peláez A, Cazals A et al. Neutrophil-tolymphocyte ratio: A potential new peripheral biomarker of suicidal behavior. Eur Psychiatry 2020; 63(1): e14-e14.

96. Verma S, Trivedi JK, Singh H, Dalal PK, Asthana OP, Srivastava JS et al. Serum lipid profile in suicide attempters. Indian J Psychiatry 1999; 41(4): 300-306.

97. Yagci I, Avci S. Biochemical predictors in presentations to the emergency department after a suicide attemp. Bratisl Lek Listy 2021; 122(3): 224-229.

98. Sudol K, Mann JJ. Biomarkers of Suicide Attempt Behavior: Towards a Biological Model of Risk. Curr Psychiatry Rep 2017; 19(6): 31. 
99. Leonard B, Maes M. Mechanistic explanations how cell-mediated immune activation, inflammation and oxidative and nitrosative stress pathways and their sequels and concomitants play a role in the pathophysiology of unipolar depression. Neurosci Biobehav Rev 2012; 36(2): 764785.

100. Morris G, Fernandes BS, Puri BK, Walker AJ, Carvalho AF, Berk M. Leaky brain in neurological and psychiatric disorders: Drivers and consequences. Aust N Z J Psychiatry 2018; 52(10): 924-948.

101. Maes M, Moraes JB, Bonifacio KL, Barbosa DS, Vargas HO, Michelin AP et al. Towards a new model and classification of mood disorders based on risk resilience, neuro-affective toxicity, staging, and phenome features using the nomothetic network psychiatry approach. Metab Brain Dis 2021; 36(3): 509-521.

102. Baumeister D, Akhtar R, Ciufolini S, Pariante CM, Mondelli V. Childhood trauma and adulthood inflammation: a meta-analysis of peripheral C-reactive protein, interleukin- 6 and tumour necrosis factor-a. Molecular Psychiatry 2016; 21(5): 642-649.

103. Qin T, Liu W, Yin M, Shu C, Yan M, Zhang J et al. Body mass index moderates the relationship between C-reactive protein and depressive symptoms: evidence from the China Health and Retirement Longitudinal Study. Scientific Reports 2017; 7(1): 39940.

104. Hjorth øj CR, Madsen T, Agerbo E, Nordentoft M. Risk of suicide according to level of psychiatric treatment: a nationwide nested case-control study. Soc Psychiatry Psychiatr Epidemiol 2014; 49(9): 1357-1365. 
Figure 1. PRISMA 2020 diagram

\section{Identification of new studies via databases and registers}
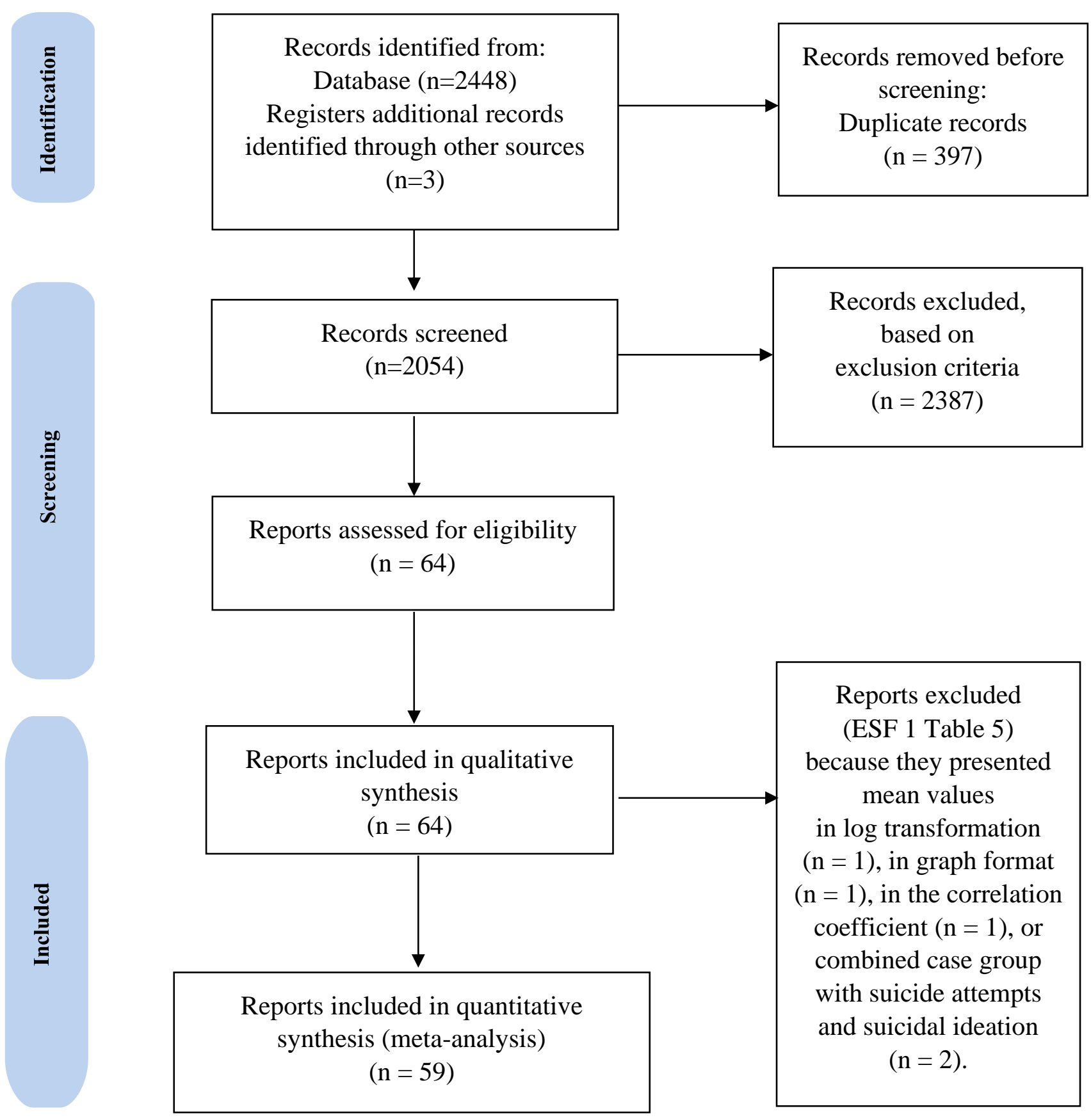
Table 1. Number of cases with suicidal attempts (SA+), suicidal ideation (SI+) and controls in the different meta-analyses and side of standardized mean difference (SMD) and the 95\% confidence intervals with respect to zero SMD.

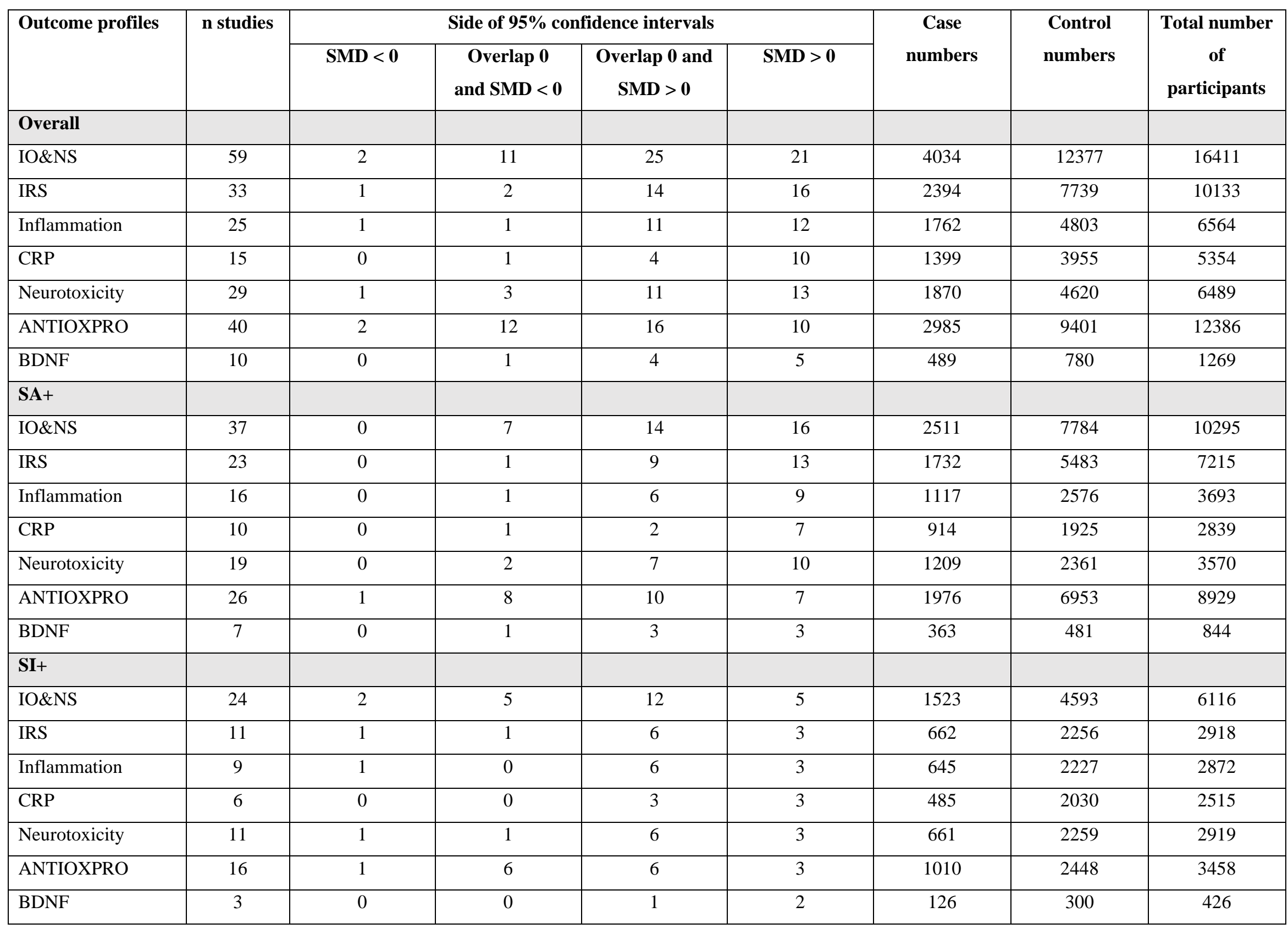




\section{doi:10.20944/preprints202109.0159.v1}

IO\&NS: immune-inflammatory and oxidative and nitrosative stress

IRS: immune-inflammatory response system

ANTIOXPRO: protection via antioxidants and neurotrophic products.

CRP: C-reactive protein

BDNF: Brain-derived neurotrophic factor 
Table 2. Results of meta-analysis performed on different outcome variables (immune and oxidative and nitrosative stress profiles, IO\&NS, and subdomains)

\begin{tabular}{|c|c|c|c|c|c|c|c|c|c|c|c|c|}
\hline $\begin{array}{c}\text { Outcome } \\
\text { feature sets }\end{array}$ & $\begin{array}{c}\text { n } \\
\text { studies }\end{array}$ & $\begin{array}{c}\text { Groups, } \\
\text { subgroups }\end{array}$ & SMD & $95 \% \mathrm{CI}$ & $\mathbf{z}$ & $\mathbf{p}$ & $\bar{Q}$ & df & $\mathbf{p}$ & $\begin{array}{c}I^{2} \\
(\%)\end{array}$ & $\overline{\tau^{2}}$ & $T$ \\
\hline \multirow[t]{5}{*}{ IO\&NS } & 59 & Overall & 0.299 & $0.200 ; 0.397$ & 5.933 & $<0.001$ & 276.474 & 58 & $<0.001$ & 79.022 & 0.100 & 0.316 \\
\hline & 37 & SA+vs. Controls & 0.387 & $0.256 ; 0.519$ & 5.771 & $<0.001$ & 176.200 & 36 & $<0.001$ & 79.569 & 0.114 & 0.337 \\
\hline & 21 & $\mathrm{SA}+v s . \mathrm{HC}$ & 0.796 & $0.503 ; 1.089$ & 5.322 & $<0.001$ & 152.636 & 20 & $<0.001$ & 86.897 & 0.393 & 0.627 \\
\hline & 29 & $\mathrm{SA}+v s . \mathrm{SA}-$ & 0.255 & $0.140 ; 0.370$ & 4.344 & $<0.001$ & 90.748 & 28 & $<0.001$ & 69.145 & 0.056 & 0.238 \\
\hline & 24 & SI+ vs. Controls & 0.167 & $0.030 ; 0.304$ & 2.396 & 0.017 & 83.446 & 23 & $<0.001$ & 72.437 & 0.071 & 0.267 \\
\hline \multirow[t]{5}{*}{ IRS } & 33 & Overall & 0.460 & $0.314 ; 0.605$ & 6.186 & $<0.001$ & 174.008 & 32 & $<0.001$ & 81.610 & 0.128 & 0.358 \\
\hline & 23 & SA+vs. Controls & 0.590 & $0.400 ; 0.779$ & 6.101 & $<0.001$ & 133.065 & 22 & $<0.001$ & 83.467 & 0.158 & 0.398 \\
\hline & 14 & $\mathrm{SA}+v s . \mathrm{HC}$ & 1.049 & $0.637 ; 1.462$ & 4.983 & $<0.001$ & 118.960 & 13 & $<0.001$ & 89.072 & 0.534 & 0.731 \\
\hline & 17 & $\mathrm{SA}+v s . \mathrm{SA}-$ & 0.384 & $0.229 ; 0.538$ & 4.855 & $<0.001$ & 56.249 & 16 & $<0.001$ & 71.555 & 0.064 & 0.254 \\
\hline & 11 & SI+ vs. Controls & 0.231 & $0.033 ; 0.430$ & 2.281 & 0.023 & 28.265 & 10 & 0.002 & 64.621 & 0.063 & 0.251 \\
\hline \multirow[t]{5}{*}{ Inflammation } & 25 & Overall & 0.459 & $0.284 ; 0.633$ & 5.142 & $<0.001$ & 147.659 & 24 & $<0.001$ & 83.746 & 0.146 & 0.382 \\
\hline & 16 & SA $+v s$. Controls & 0.623 & $0.388 ; 0.858$ & 5.199 & $<0.001$ & 95.325 & 15 & $<0.001$ & 84.264 & 0.173 & 0.415 \\
\hline & 9 & $\mathrm{SA}+v s . \mathrm{HC}$ & 1.200 & $0.584 ; 1.816$ & 3.820 & $<0.001$ & 90.393 & 8 & $<0.001$ & 91.150 & 0.791 & 0.889 \\
\hline & 13 & $\mathrm{SA}+v s . \mathrm{SA}-$ & 0.414 & $0.223 ; 0.605$ & 4.250 & $<0.001$ & 47.029 & 12 & $<0.001$ & 74.484 & 0.080 & 0.282 \\
\hline & 10 & SI+ vs. Controls & 0.239 & $0.000 ; 0.478$ & 1.962 & 0.050 & 36.317 & 9 & $<0.001$ & 75.218 & 0.099 & 0.315 \\
\hline \multirow[t]{5}{*}{ CRP } & 15 & Overall & 0.573 & $0.366 ; 0.780$ & 5.433 & $<0.001$ & 99.036 & 14 & $<0.001$ & 85.864 & 0.128 & 0.358 \\
\hline & 10 & SA+vs. Controls & 0.689 & $0.386 ; 0.991$ & 4.463 & $<0.001$ & 78.523 & 9 & $<0.001$ & 88.538 & 0.194 & 0.440 \\
\hline & 4 & $\mathrm{SA}+v s . \mathrm{HC}$ & 1.311 & $0.446 ; 2.177$ & 2.969 & 0.003 & 32.712 & 3 & $<0.001$ & 90.829 & 0.704 & 0.839 \\
\hline & 8 & $\mathrm{SA}+v s . \mathrm{SA}-$ & 0.499 & $0.234 ; 0.764$ & 3.696 & $<0.001$ & 43.082 & 7 & $<0.001$ & 83.752 & 0.110 & 0.331 \\
\hline & 6 & SI+ vs. Controls & 0.429 & $0.161 ; 0.697$ & 3.138 & 0.002 & 18.524 & 5 & 0.002 & 73.009 & 0.075 & 0.274 \\
\hline \multirow[t]{3}{*}{ Neurotoxicity } & 29 & Overall & 0.403 & $0.253 ; 0.553$ & 5.262 & $<0.001$ & 133.901 & 28 & $<0.001$ & 79.089 & 0.116 & 0.340 \\
\hline & 19 & SA $+v s$. Controls & 0.524 & $0.320 ; 0.727$ & 5.048 & $<0.001$ & 94.676 & 18 & $<0.001$ & 80.988 & 0.147 & 0.383 \\
\hline & 12 & $\mathrm{SA}+v s . \mathrm{HC}$ & 0.904 & $0.431 ; 1.378$ & 3.745 & $<0.001$ & 106.480 & 11 & $<0.001$ & 89.669 & 0.607 & 0.779 \\
\hline
\end{tabular}




\begin{tabular}{|c|c|c|c|c|c|c|c|c|c|c|c|c|}
\hline & 14 & $\mathrm{SA}+v s . \mathrm{SA}-$ & 0.403 & $0.218 ; 0.588$ & 4.278 & $<0.001$ & 49.022 & 13 & $<0.001$ & 73.481 & 0.079 & 0.282 \\
\hline & 11 & SI+ vs. Controls & 0.243 & $0.036 ; 0.449$ & 2.299 & 0.021 & 30.692 & 10 & 0.001 & 67.418 & 0.072 & 0.268 \\
\hline \multirow[t]{5}{*}{ ANTIOXPRO } & 40 & Overall & 0.179 & $0.063 ; 0.294$ & 3.031 & 0.002 & 196.268 & 39 & $<0.001$ & 80.129 & 0.095 & 0.308 \\
\hline & 26 & $\mathrm{SA}+v s$. Controls & 0.199 & $0.058 ; 0.341$ & 2.761 & 0.006 & 119.840 & 25 & $<0.001$ & 79.139 & 0.091 & 0.302 \\
\hline & 13 & $\mathrm{SA}+v s . \mathrm{HC}$ & 0.476 & $0.083 ; 0.869$ & 2.372 & 0.018 & 118.374 & 12 & $<0.001$ & 89.863 & 0.461 & 0.679 \\
\hline & 22 & SA+vs. SA- & 0.137 & $0.021 ; 0.253$ & 2.322 & 0.020 & 58.340 & 21 & $<0.001$ & 64.004 & 0.039 & 1.197 \\
\hline & 16 & SI+ vs. Controls & 0.141 & $-0.056 ; 0.338$ & 1.401 & 0.161 & 73.159 & 15 & $<0.001$ & 79.497 & 0.113 & 0.336 \\
\hline \multirow[t]{5}{*}{ BDNF } & 10 & Overall & 0.479 & $0.224 ; 0.735$ & 3.681 & $<0.001$ & 34.811 & 9 & $<0.001$ & 74.146 & 0.118 & 0.344 \\
\hline & 7 & $\mathrm{SA}+v s$. Controls & 0.417 & $0.102 ; 0.733$ & 2.590 & 0.010 & 25.883 & 6 & $<0.001$ & 76.819 & 0.131 & 0.362 \\
\hline & 4 & $\mathrm{SA}+v s . \mathrm{HC}$ & 0.962 & $0.708 ; 1.217$ & 7.416 & $<0.001$ & 2.628 & 3 & 0.453 & 0.000 & 0.000 & 0.000 \\
\hline & 6 & $\mathrm{SA}+v s . \mathrm{SA}^{-}$ & 0.256 & $-0.026 ; 0.538$ & 1.779 & 0.075 & 14.800 & 5 & 0.011 & 66.217 & 0.076 & 0.275 \\
\hline & 3 & SI+ vs. Controls & 0.665 & $0.413 ; 0.917$ & 5.169 & $<0.001$ & 2.039 & 2 & 0.361 & 1.934 & 0.001 & 0.032 \\
\hline
\end{tabular}

SMD: standardized mean difference, $95 \%$ CI: $95 \%$ confidence intervals

IO\&NS: immune-inflammatory and oxidative and nitrosative stress

IRS: immune-inflammatory response system

ANTIOXPRO: protection via antioxidants and neurotrophic products.

CRP: C-reactive protein

BDNF: Brain-derived neurotrophic factor

We used the study as well as the prespecified subgroups as the units of analysis. Thus, patients with suicide behaviors (SB) were first (overall) compared with controls. Second, we performed subgroup analyses comparing the pooled effect size of IO\&NS, IRS, inflammation, CRP, neurotoxicity, ANTIOXPRO and BDNF profiles in a) SA+ versus SA- patients or healthy controls); and b) SI+ versus SI- patients or healthy controls. 


\section{IO\&NS profile in suicide behaviors}

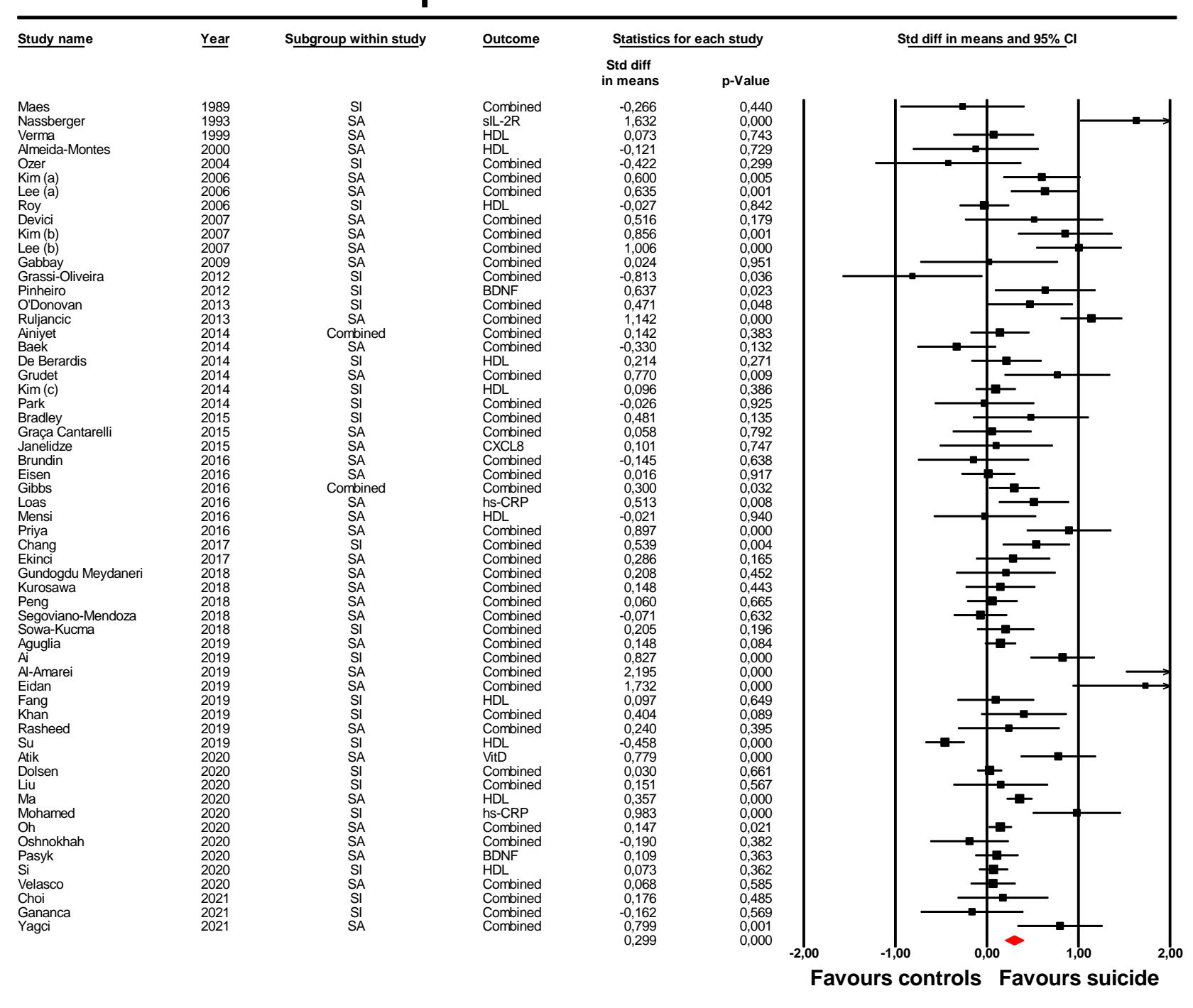

Vasupanrajit et al. 
Figure 2. Forest plot with results of meta-analysis performed on 59 studies reporting immuneinflammatory and oxidative $\&$ nitrosative stress (IO\&NS) biomarkers. 


\section{Inflammation in SA/SI}

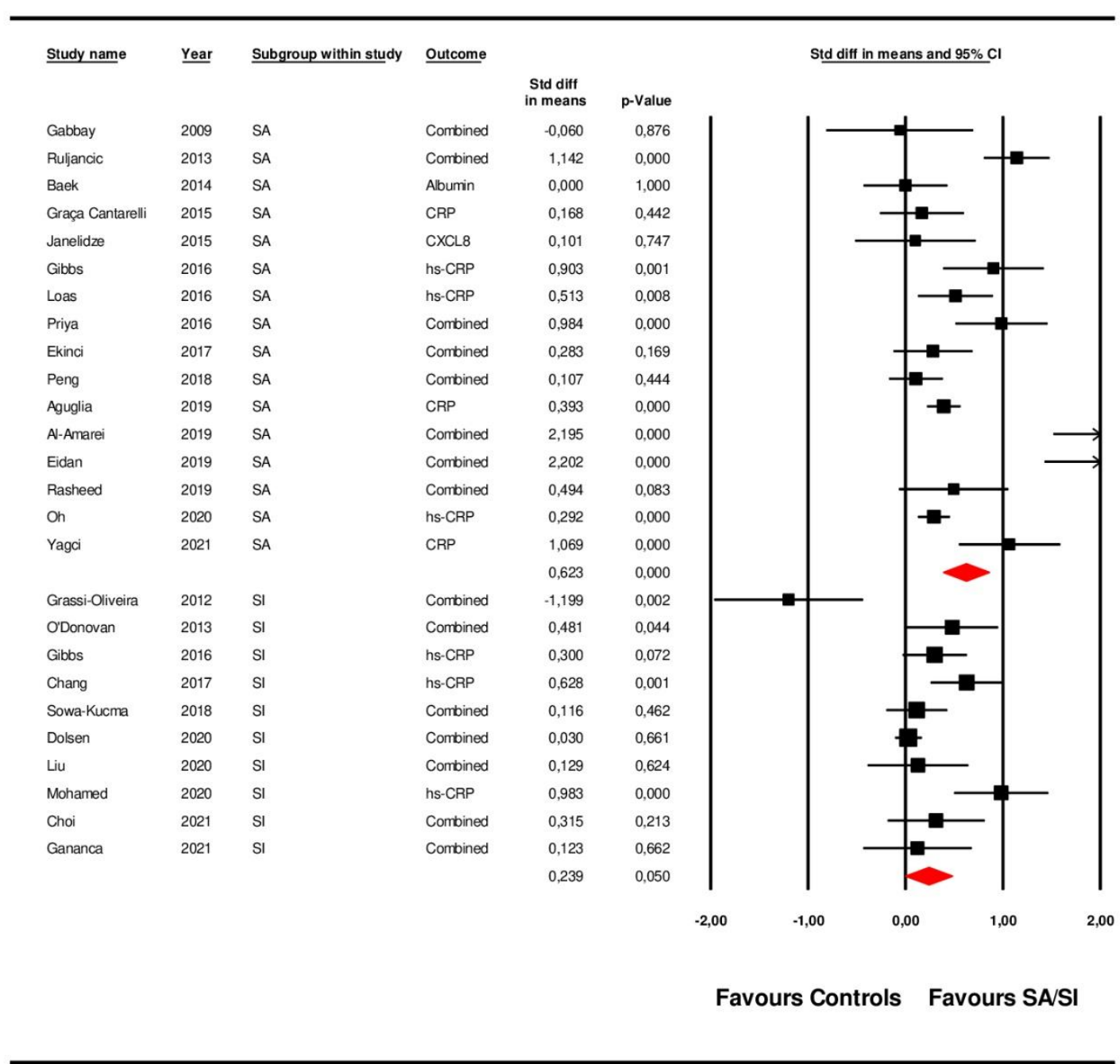

Vasupanrajit et al. 
40

Figure 3. Forest plot with results of meta-analysis (subgroup analysis) performed on 26 studies reporting inflammation profile. 


\section{Electronic Supplementary Information File (ESF) 1}

Activated immune, oxidative and nitrosative stress pathways are strongly associated with suicidal attempts and less with suicidal ideation: a meta-analysis and meta-regression.

Running title: immune activation in suicidal behaviors

Asara Vasupanrajit, M.Sc. ${ }^{\text {aj }}$ Ketsupar Jirakran, M.Sc. ${ }^{\text {a,b }}$; Chavit Tunvirachaisakul, M.D., Ph.D. ${ }^{\text {a, c }}$; Michael Maes, M.D., Ph.D. ${ }^{\text {a, c, d, e }}$

${ }^{a}$ Department of Psychiatry, Faculty of Medicine, Chulalongkorn University, Bangkok, Thailand.

b Maximizing Thai Children's Developmental Potential Research Unit, Department of Pediatrics, Faculty of Medicine, Chulalongkorn University, Bangkok, Thailand.

${ }^{c}$ Cognitive Impairment and Dementia Research Unit, Department of Psychiatry, Faculty of Medicine, Chulalongkorn University, Bangkok, Thailand.

${ }^{\mathrm{d}}$ IMPACT Strategies Research Center, Deakin University, Geelong, Australia.

${ }^{\mathrm{e}}$ Department of Psychiatry, Medical University of Plovdiv, Plovdiv, Bulgaria. 
ESF 1 Table 1. Explanation of peripheral immune and O\&NS phenotypes.

\begin{tabular}{|c|c|c|c|c|}
\hline \multicolumn{2}{|c|}{ Immune and O\&NS phenotype } & What is & What examined & $\begin{array}{l}\text { What is missing in } \\
\text { SA research }\end{array}$ \\
\hline \multirow{6}{*}{$\operatorname{IRS}^{1,2}$} & Inflammation (M1) & $\begin{array}{l}\text { M1 cytokines, Acute Phase } \\
\text { Proteins (APR), Complement }\end{array}$ & $\begin{array}{c}\text { Interleukin (IL)-6, } \\
\text { Tumor necrosis factor } \\
\text { (TNF)- } \alpha, \\
\text { IL-1 } \beta, \\
\text { C-reactive protein } \\
\text { (CRP), Albumin, CCL2, } \\
\text { CXCL8 }\end{array}$ & $\begin{array}{l}\text { Fibrinogen sIL-6R, } \\
\text { soluble gp130, } \\
\text { sTNF- } \alpha \mathrm{R} 1, \\
\text { sIL-1RA, } \\
\text { complement factors }\end{array}$ \\
\hline & T helper (Th)-1 & IL-2, Interferon (IFN)- $\gamma$, IL-12 & $\begin{array}{l}\text { IL-2, IFN- } \gamma, \text { IL2/IL4, } \\
\text { IFN- } \gamma / \text { IL4 }\end{array}$ & IL-12 \\
\hline & $\begin{array}{l}\text { Cell-mediated } \\
\text { immunity (CMI) }\end{array}$ & Interaction $\mathrm{M} 1$ and $\mathrm{Th} 1$ & $\begin{array}{c}\text { IL-6, TNF- } \alpha, \text { IL-1, IL-2, } \\
\text { IFN- } \gamma \text {, } \\
\text { sIL-2R, TRYCATS (i.e., } \\
\text { PA, QA, KYN), } \\
\text { Tryptophan }\end{array}$ & Neopterin \\
\hline & Th-17 & IL-6, IL-17 & IL-6 & IL-17 \\
\hline & Chemokines & CXCL-8, eotaxin & $\begin{array}{c}\text { CXCL-8, CCL2, CCL11, } \\
\text { RANTES }\end{array}$ & eotaxin, etc \\
\hline & APR proteins & $\begin{array}{c}\text { Plasminogen Activator Inhibitor-1 } \\
\text { (PAI-1), Haptoglobin (Hp), serum } \\
\text { amyloid A and P, alpha-1 acid, } \\
\text { complement system } \\
\text { (such as C3 and C4), CRP, Fb, } \\
\text { Albumin }\end{array}$ & CRP, Albumin & $\begin{array}{l}\text { Fibrinogen, Hp, } \\
\text { PAI-1, retinol } \\
\text { binding protein } \\
\text { (RBP) }\end{array}$ \\
\hline \multirow{2}{*}{$\mathrm{CIRS}^{1,2}$} & $\begin{array}{l}\text { Regulatory T cells } \\
\text { (T-reg) }\end{array}$ & $\begin{array}{l}\text { IL-10, Transforming growth factor } \\
\text { (TGF)- } \beta\end{array}$ & TGF- $\beta$ & $\begin{array}{l}\text { T-reg cells } \\
\text { CD4, CD25, } \\
\text { Forkhead box P3 } \\
\text { (FOXP3), TGF- } \beta\end{array}$ \\
\hline & Th-2 & $\begin{array}{l}\text { IL-4, IL-5, IL-9, IL-10, IL-13 and } \\
\text { IL-25 }\end{array}$ & IL-4 & IL-13, IL-5, IL-9 \\
\hline \multirow{2}{*}{$\mathrm{O} \& \mathrm{NS}^{1,2}$} & $\begin{array}{l}\text { Nitro-oxidative } \\
\text { stress }\end{array}$ & $\begin{array}{c}\text { Advanced oxidation protein } \\
\text { products (AOPP), Homocysteine, } \\
\text { Lipid Hydroperoxide (LOOH), } \\
\text { 3,4-Methylenedioxyamphetamine } \\
\text { (MDA), Nitric oxide metabolites } \\
\text { (NOx) }\end{array}$ & MDA, NOx, TBARS & $\begin{array}{l}\text { DNA oxidation } \\
\text { damage to } \\
\text { mitochondria, } \\
\text { AOPP, } \\
\text { Homocysteine, } \\
\text { LOOH }\end{array}$ \\
\hline & Antioxidant & $\begin{array}{l}\text { Albumin, BDNF, HDL-c, } \\
\text { total reactive antioxidant potential } \\
\text { (TRAP), Vitamin D }\end{array}$ & $\begin{array}{l}\text { Albumin, BDNF, DHA, } \\
\text { EPA, HDL-c, TAC, } \\
\text { Tryptophan, Vitamin D }\end{array}$ & $\begin{array}{c}\text { Catalase, } \\
\text { Vitamin A, Vitamin } \\
\text { C, Vitamin E, } \\
\text { Coenzyme Q10, } \\
\text { Zinc, Glutathione }\end{array}$ \\
\hline NT & Neurotoxicity $^{3}$ & IRS, CIRS, Nitro-oxidative stress & $\begin{array}{l}\text { AA, CCL1, CCL2, } \\
\text { CCL3, RANTES, } \\
\text { CCL11, CCL17, CCL22, } \\
\text { CCL23, CCL24, CCL27, } \\
\text { CX3CL1, CXCL2, } \\
\text { CXCL5, CXCL8, } \\
\text { CXCL10, CXCL12, }\end{array}$ & $\begin{array}{l}\text { LPS bacteria, } \\
\text { indicants BBB, } \\
\text { AOPP, } \\
\text { Homocysteine, } \\
\text { LOOH, }\end{array}$ \\
\hline
\end{tabular}




\begin{tabular}{|c|c|c|c|c|}
\hline & & & $\begin{array}{c}\text { CXCL16, CRP, IFN- } \gamma \text {, } \\
\text { IL-1 } \beta \text {, IL-2, IL-6, TNF- } \\
\alpha, \text { TRYCATS (i.e., PA, } \\
\text { QA, KYN), MDA, NOx, } \\
\text { TBARS, TNFR60, } \\
\text { TNFR80 }\end{array}$ & \\
\hline NP & Neuroprotection $^{3}$ & Antioxidant & $\begin{array}{c}\text { Albumin, BDNF, DHA, } \\
\text { EPA, HDL-c, TAC, } \\
\text { Trytophan, Vitamin D }\end{array}$ & $\begin{array}{c}\text { Vitamin E, } \\
\text { Coenzyme Q10, } \\
\text { Zinc, Glutathione }\end{array}$ \\
\hline
\end{tabular}

Note: Further explanation of the function of the peripheral immune and O\&NS phenotypes can be found in Maes and Carvalho, $2018^{1}$; Roomruangwong et al., $2020^{2}$ and Maes et al., $2021^{3}$

1. Maes M, Carvalho AF. The Compensatory Immune-Regulatory Reflex System (CIRS) in Depression and Bipolar Disorder. Mol Neurobiol 2018; 55(12): 8885-8903.

2. Roomruangwong C, Noto C, Kanchanatawan B, Anderson G, Kubera M, Carvalho AF et al. The Role of Aberrations in the Immune-Inflammatory Response System (IRS) and the Compensatory Immune-Regulatory Reflex System (CIRS) in Different Phenotypes of Schizophrenia: the IRS-CIRS Theory of Schizophrenia. Mol Neurobiol 2020; 57(2): 778-797.

3. Maes M, Moraes JB, Bonifacio KL, Barbosa DS, Vargas HO, Michelin AP et al. Towards a new model and classification of mood disorders based on risk resilience, neuro-affective toxicity, staging, and phenome features using the nomothetic network psychiatry approach. Metabolic brain disease 2021; 36(3): 509-521.

Abbreviations:

AA: Arachidonic acid (omega-6 fatty acid)

APR: the acute phase response

BBB: Blood-Brain Barrier

BDNF: Brain-derived neurotrophic factor

CCL: The $\mathrm{C}-\mathrm{C}$ motif chemokine ligand

CIRS: The compensatory immune-regulatory reflex system

CXCL: The chemokine $\mathrm{C}-\mathrm{X}-\mathrm{C}$ motif ligand

CX3CL1: The C-X3-C Motif Chemokine Ligand 1/Fractalkine

DHA: Docosahexaenoic acid (omega-3 fatty acid)

EPA: Eicosapentaenoic acid (omega-3 fatty acid)

HDL-c: High-density lipoprotein cholesterol

IRS: The immune-inflammatory response system

KYN: Kynurenine

LPS: Lipopolysaccharides

MDA: Malondialdehyde

NOx: Nitric oxide metabolites

NT: Neurotoxicity

NP: Neuroprotection

O\&NS: Antioxidants and nitro-oxidative stress

PA: Picolinic acid

QA: Quinolinic acid

RANTES: Regulated on Activation, Normal T Cell Expressed and Secreted

SA: Suicide attempts

SI: Suicide ideation

sIL2R: Soluble Interleukin 2 Receptor

sIL6R: Soluble Interleukin 6 Receptor

sTNF- $\alpha$ R1: Soluble tumor necrosis factor alpha receptor 1

TAC: Total antioxidant capacity

TBARS: Thiobarbituric acid reactive substances

TNFR: Tumor necrosis factor receptors

TRYCATs: The tryptophan catabolites 
ESF 1 Table 2. Specific search for each database.

\begin{tabular}{|l|}
\hline PubMed/Medline \\
\hline ((inflamm* OR immun*) AND (cytokine OR chemokine OR il-6 OR il-1 OR interleukin OR (c-reactive protein \\
Tryptophan AND (suicid*)) 1072 \\
\hline PubMed/Medline \\
\hline ((Oxidative stress OR Antioxidants) AND (Zinc) OR (Vitamin C) OR (Albumin) OR (Nitric oxide metabolites) \\
OR (Lipid hydroperoxides) OR (Omega 3) OR (Coenzyme Q10) OR (DHA) AND (suicid*) 406 \\
\hline Google Scholar \\
\hline Suicide AND [inflamm*] OR [immun*] AND [oxidative stress biomarkers] AND antioxidants OR [cytokine] OR \\
chemokine] OR [il-6 OR il-1 OR interleukin] OR [(c-reactive protein) OR CRP] OR [(Tumor necrosis factor) OR \\
tnf] OR [interferon OR ifn] OR (Transforming) 617 \\
\hline WEB OF SCIENCE \\
\hline TOPIC: (Suicide AND Oxidative Stress) 353 \\
\hline
\end{tabular}


ESF 1 Table 3. Immune confounder of suicide behaviors scale (ICS); applied from Andrés-Rodríguez, et al., 2019a and Vasupanrajit et al., 2021 ${ }^{\mathrm{b}}$

\section{Methodological quality of the study}

$1 \quad$ Study sample $\geq 128$ participants including patients and controls $(1=$ Yes, $0=$ No $)$

2 Did the study control results for potential confounders (e.g., age, BMI, gender, race)? $(1=$ Yes, $0=$ No)

3 Were participants with suicide attempts (SA) and controls age- and-gender-matched or statistically controlled? $(1=$ Yes, $0=$ No)

4 Was the time of sample collection specified (e.g., morning vs. evening)? $(1=$ Yes, $0=$ No)

5 Were participants with SA free of immunomodulatory drugs including anti-cytokines, corticoids, immunoglobulins, and immunosuppressants, been through a medication washout or the intake was statistically controlled? $(1=$ Yes, $0=$ No)

6 Were participants with suicidal behaviour free of antidepressants and mood stabilizers or statistically controlled? $(1=$ Yes, $0=$ No $)$

7 Reporting of either the manufacturer of the test or its parameters (detection limit and coefficient of variation) $(1=$ Yes, $0=$ No)

8 Reporting how data under detection limit was handled $(1=$ Yes, $0=$ No $)$

9 Reporting $\%$ of the sample under detection limit $(1=$ Yes, $0=$ No)

10 Reporting blood fraction (serum, plasma, culture supernatant or whole blood) $(1=$ Yes, $0=$ No)

Total quality score (10 points)

\section{Biomarker confounders red points}

The red points should not be given if the item is statistically controlled

13 red points for comorbid illnesses such as autoimmune disorders \& other immune disorders including RA, psoriasis, IBD, COPD, MS

23 red points for use of recreational drugs such as methamphetamine or opioids (Not applicable if psychiatric disorders are excluded)

32 red points when groups were significantly difference or there was no statistically controlled for age

42 red points when groups were significantly difference or there was no statistically controlled for sex

52 red points for medication use as for example immunomodulators

$6 \quad 2$ red points for early traumatic life events

$7 \quad 2$ red points for shift work and primary sleep disorders 
$8 \quad 1.5$ red points for antidepressants

91 red point for more common systemic immune disorders including diabetes type $1 / 2$, essential hypertension, metabolic syndrome

101 red point for not fasting ( 8 hours before blood extraction)

111 red point for use of omega-3 and antioxidant supplements

121 red point when groups were significantly difference or there was no statistically controlled for BMI

131 red point for physical activity or sedentary life

141 red point for smoking

151 red point for use of oral contraceptives or NSAIDs

160.5 red points for ethnicity in countries such as US, Brazil (not China or Japan)

170.5 red points for seasonality

180.5 red points for diurnal variation (8-10 a.m. versus all other time points)

Total red point score ( 26 points)

Note: Threshold of study samples is stablished as it is the minimum needed for statistical power. Confounders red points should be given when the item is not reported (or statistically controlled).

a Andrés-Rodríguez L, Borràs X, Feliu-Soler A, Pérez-Aranda A, Angarita-Osorio N, Moreno-Peral P et al. Peripheral immune aberrations in fibromyalgia: A systematic review, meta-analysis and meta-regression. Brain, Behavior, and Immunity 2020; 87: 881-889.

b Vasupanrajit A, Jirakran K, Tunvirachaisakul C, Maes M. Suicide attempts are associated with activated immune-inflammatory, nitro-oxidative, and neurotoxic pathways: A systematic review and meta-analysis. Journal of Affective Disorders 2021; 295: 8092. 
ESF 1 Table 4. Characteristics of 59 studies included in quantitative synthesis (meta-analysis).

\begin{tabular}{|c|c|c|c|c|c|c|c|c|c|c|c|c|}
\hline \multirow{2}{*}{ Authors (Year) } & \multirow{2}{*}{$\begin{array}{l}\text { Sub } \\
\text { groups }\end{array}$} & \multicolumn{2}{|c|}{$\mathbf{N}$} & \multirow{2}{*}{$\begin{array}{l}\text { Psychiatric } \\
\text { disorders in } \\
\text { cases }\end{array}$} & \multirow{2}{*}{$\begin{array}{c}\text { Suicide } \\
\text { assessment }\end{array}$} & \multirow{2}{*}{$\begin{array}{l}\text { Exclusion of } \\
\text { comorbid } \\
\text { illnesses } \\
\end{array}$} & \multirow{2}{*}{$\begin{array}{c}\text { Specific } \\
\text { time of } \\
\text { blood } \\
\text { sample } \\
\end{array}$} & \multirow{2}{*}{ Medium } & \multirow{2}{*}{$\begin{array}{l}\text { IO\&NS } \\
\text { markers }\end{array}$} & \multirow[b]{2}{*}{ Key findings } & \multirow{2}{*}{$\begin{array}{c}\begin{array}{c}\text { Quality } \\
\text { score } \\
(\max =10)\end{array} \\
\end{array}$} & \multirow{2}{*}{$\begin{array}{c}\text { Redpoint } \\
\text { score } \\
(\max =26)\end{array}$} \\
\hline & & Cases & Controls & & & & & & & & & \\
\hline $\begin{array}{l}\text { Aguglia et al. } \\
(2019)\end{array}$ & SA & 432 & 200 & Mixed & After SA & No & Yes & Serum & $\begin{array}{l}-\mathrm{CRP} \\
\text { - } \mathrm{HDL}\end{array}$ & $\begin{array}{l}\text { CRP levels in SA+ were } \\
\text { significantly higher than in SA-, } \\
\text { whereas no significant difference in } \\
\text { HDL. }\end{array}$ & 6.9 & 18.5 \\
\hline $\begin{array}{l}\text { Ai et al. } \\
\text { (2019) }\end{array}$ & SI & 84 & 66 & MDD & Self-report & No & No & Plasma & BDNF & $\begin{array}{l}\text { No significant difference in BDNF } \\
\text { between SI+ and SI-. }\end{array}$ & 4.7 & 18.0 \\
\hline $\begin{array}{l}\text { Ainiyet \& } \\
\text { Rybakowski } \\
(2014)\end{array}$ & SA, SI & 65 & 159 & Affective & Interview & Partly & Yes & Serum & $\mathrm{HDL}$ & $\begin{array}{l}\text { No significant difference in HDL } \\
\text { was observed. }\end{array}$ & 3.8 & 19.5 \\
\hline $\begin{array}{l}\text { Al-Amarei } \\
\text { et al. (2019) }\end{array}$ & SA & 22 & 34 & MDD & After SA & Partly & Partly & Plasma & CRP & $\begin{array}{l}\text { CRP levels in SA+ were } \\
\text { significantly higher than in SA- or } \\
\text { HC. }\end{array}$ & 4.0 & 15.0 \\
\hline $\begin{array}{l}\text { Almeida-Montes } \\
\text { et al. (2000) }\end{array}$ & SA & 18 & 15 & MDD & After SA & Yes & Yes & Serum & $-\mathrm{HDL}$ & $\begin{array}{l}\text { No significant difference in HDL } \\
\text { between SA+ and SA-. }\end{array}$ & 6.3 & 11.5 \\
\hline $\begin{array}{l}\text { Atik et al. } \\
(2020)\end{array}$ & SA & 59 & 42 & Mixed & After SA & No & No & Serum & Vitamin D & $\begin{array}{l}\text { Vitamin D levels in SA+ were } \\
\text { significantly lower than in HC. }\end{array}$ & 4.1 & 20.5 \\
\hline $\begin{array}{l}\text { Baek et al. } \\
\text { (2014) }\end{array}$ & SA & 22 & 464 & MDD & Interview & No & Yes & Serum & $\begin{array}{l}\text { - Albumin } \\
\text { - HDL }\end{array}$ & $\begin{array}{l}\text { HDL levels in SA+ were } \\
\text { significantly higher than in SA-. } \\
\text { - Albumin levels were not } \\
\text { significantly different. }\end{array}$ & 5.7 & 19.0 \\
\hline $\begin{array}{l}\text { Bradley et al. } \\
\text { (2015) }\end{array}$ & SI & 19 & 26 & MDD & Self-report & Partly & Yes & Plasma & $\begin{array}{l}\text { - KYN } \\
\text { - TRP } \\
\text { - KYN/TRP }\end{array}$ & $\begin{array}{l}\text { TRP levels in SA+ were } \\
\text { significantly lower than in SA- or } \\
\text { HC, whereas KYN levels were not } \\
\text { substantially different. } \\
\text { KYN/TRP ratio in SA+ were } \\
\text { significantly higher than in SA- or } \\
\text { HC. }\end{array}$ & 7.2 & 12.0 \\
\hline $\begin{array}{l}\text { Brundin et al. } \\
\text { (2016) }\end{array}$ & SA & 18 & 29 & $\begin{array}{l}\text { MDD, } \\
\text { Affective }\end{array}$ & After SA & No & Yes & Plasma & $\begin{array}{l}-\mathrm{PA} \\
-\mathrm{QA}\end{array}$ & $\begin{array}{l}\text { PA levels in SA+ with mixed group } \\
\text { of psychiatric disorders were } \\
\text { significantly lower than in HC, } \\
\text { whereas QA levels were not } \\
\text { substantially different. }\end{array}$ & 6.3 & 23.8 \\
\hline \multirow[t]{2}{*}{$\begin{array}{l}\text { Chang et al. } \\
\text { (2017) }\end{array}$} & \multirow[t]{2}{*}{ SI } & \multirow[t]{2}{*}{58} & \multirow[t]{2}{*}{61} & \multirow[t]{2}{*}{ MDD } & \multirow[t]{2}{*}{ Interview } & \multirow[t]{2}{*}{ Partly } & \multirow[t]{2}{*}{ Yes } & Blood & - ESR & \multirow{2}{*}{$\begin{array}{l}\text { ESR and hs-CRP levels in SI+ } \\
\text { were significantly higher than in } \\
\text { SI-. }\end{array}$} & \multirow[t]{2}{*}{7.0} & \multirow[t]{2}{*}{10.8} \\
\hline & & & & & & & & Serum & - hs-CRP & & & \\
\hline $\begin{array}{l}\text { Choi et al. } \\
(2021)\end{array}$ & SI & 23 & 59 & MDD, Other & Self-report & Partly & Yes & Serum & $\begin{array}{l}\text { hs-CRP } \\
- \text { IFN- } \gamma \\
\text { - IL-10 } \\
\text { - IL-6 } \\
\text { - TNF- } \alpha \\
\end{array}$ & $\begin{array}{l}\text { - Higher TNF- } \alpha \text { levels were a } \\
\text { significant indicator of SI in MDD } \\
\text { patients. } \\
\text { - No significant findings in SI+ } \\
\text { patients with panic disorders. }\end{array}$ & 5.0 & 22.5 \\
\hline $\begin{array}{l}\text { De Beradis et al. } \\
\text { (2014) }\end{array}$ & SI & 79 & 40 & Other & Self-report & Partly & Yes & Serum & - HDL & $\begin{array}{l}\text { No significant findings in SI+ } \\
\text { patients with OCD. However, } \\
\text { alexithymia patients with OCD } \\
\text { showed significant lower HDL } \\
\text { levels than HC. }\end{array}$ & 6.0 & 14.5 \\
\hline $\begin{array}{l}\text { Devici et al. } \\
\text { (2007) }\end{array}$ & SA & 10 & 25 & Other & After SA & No & Yes & Serum & BDNF & $\begin{array}{l}\text { Lower BDNF levels were observed } \\
\text { in SA+ and MDD patients than in } \\
\text { HC. }\end{array}$ & 5.0 & 22.5 \\
\hline
\end{tabular}




\begin{tabular}{|c|c|c|c|c|c|c|c|c|c|c|c|c|}
\hline $\begin{array}{l}\text { Dolsen et al. } \\
(2020)\end{array}$ & SI & 244 & 1733 & Mixed & Self-report & No & Yes & Plasma & $\begin{array}{l}- \text { hs-CRP } \\
\text { - IL-6 } \\
\text { - TNF- } \alpha\end{array}$ & $\begin{array}{l}\text { Higher IL-6 levels were associated } \\
\text { with SI+ in the past week. }\end{array}$ & 6.8 & 21.0 \\
\hline $\begin{array}{l}\text { Eidan et al. } \\
\text { (2019) }\end{array}$ & SA & 22 & 34 & MDD & After SA & Partly & Yes & Plasma & $\begin{array}{l}- \text { IL-6 } \\
- \text { IFN- } \gamma \\
\text { - HDL }\end{array}$ & $\begin{array}{l}\text { - Higher IL-6 and IFN- } \gamma \text { levels were } \\
\text { found in SA+ than in HC. } \\
\text { No significant difference in HDL } \\
\text { was observed. }\end{array}$ & 7.5 & 14.5 \\
\hline $\begin{array}{l}\text { Eisen et al. } \\
(2016)\end{array}$ & SA & 84 & 99 & Mixed & After SA & No & Yes & Serum & - BDNF & $\begin{array}{l}\text { No significant association between } \\
\text { BDNF and SA. }\end{array}$ & 6.6 & 19.0 \\
\hline \multirow[t]{2}{*}{$\begin{array}{l}\text { Ekinci \& Ekinci } \\
\text { (2017) }\end{array}$} & \multirow[t]{2}{*}{ SA } & \multirow[t]{2}{*}{37} & \multirow[t]{2}{*}{76} & \multirow[t]{2}{*}{ MDD } & \multirow[t]{2}{*}{ After SA } & \multirow[t]{2}{*}{ Partly } & \multirow[t]{2}{*}{ Yes } & Serum & $\begin{array}{l}\text { - HDL } \\
\text { - hs-CRP }\end{array}$ & \multirow{2}{*}{$\begin{array}{l}\text { NLR and hs-CRP levels in SA+ } \\
\text { were significantly higher than in } \\
\text { SA- or HC after adjusting the } \\
\text { confounding factors. }\end{array}$} & \multirow[t]{2}{*}{8.8} & \multirow[t]{2}{*}{9.0} \\
\hline & & & & & & & & Blood & - NLR & & & \\
\hline $\begin{array}{l}\text { Fang et al. } \\
\text { (2019) }\end{array}$ & SI & 26 & 148 & Other & Interview & Partly & Yes & Serum & - HDL & $\begin{array}{l}\text { No significant association between } \\
\text { HDL and SI+ in schizophrenia } \\
\text { patients. }\end{array}$ & 9.4 & 9.0 \\
\hline $\begin{array}{l}\text { Gabbay et al. } \\
\text { (2009) }\end{array}$ & SA & 12 & 17 & MDD & After SA & Partly & Yes & Plasma & $\begin{array}{l}\text { - IFN- } \gamma \\
\text { - TNF- } \alpha \\
\text { - IL-1 } \beta \\
\text { - IL-6 } \\
\text { - IFN- } \gamma / \text { IL-4 }\end{array}$ & $\begin{array}{l}\text { After adjusting confounding } \\
\text { variables, IFN- } \gamma \text { levels in SA+ } \\
\text { were significantly higher than in } \\
\text { HC and TNF- } \alpha \text { levels in SA+ were } \\
\text { significantly lower than in SA-. }\end{array}$ & 4.8 & 17.0 \\
\hline \multirow[t]{2}{*}{$\begin{array}{l}\text { Ganança et al. } \\
(2021)\end{array}$} & \multirow[t]{2}{*}{ SI } & \multirow[t]{2}{*}{22} & \multirow[t]{2}{*}{31} & \multirow[t]{2}{*}{ MDD } & \multirow[t]{2}{*}{ Interview } & \multirow[t]{2}{*}{ Partly } & No & Serum & $\begin{array}{l}\text { - IL- } 1 \beta \\
\text { - IL-6 } \\
\text { - TNF- } \alpha\end{array}$ & \multirow{2}{*}{$\begin{array}{l}\text { Inflammatory and lipid markers } \\
\text { revealed no significant differences } \\
\text { in SI+ when compared with SI- or } \\
\text { HC. } \\
\text { DHA\% and IL-1 } 1 \beta \text { showed lower in } \\
\text { patient with history of SA+ (within } \\
5 \text { years) when compared with SI+. }\end{array}$} & \multirow[t]{2}{*}{5.0} & \multirow[t]{2}{*}{15.0} \\
\hline & & & & & & & & Plasma & $\begin{array}{l}- \text { AA } \\
\text { - EPA } \\
\text { - DHA }\end{array}$ & & & \\
\hline $\begin{array}{l}\text { Gibbs et al. } \\
\text { (2016) }\end{array}$ & SA, SI & 129 & 110 & Mixed & $\begin{array}{l}\text { After SA, } \\
\text { Interview }\end{array}$ & No & No & Serum & $\begin{array}{l}\text { - HDL } \\
\text { - hs-CRP }\end{array}$ & $\begin{array}{l}\text { - hs-CRP levels showed significantly } \\
\text { higher in patient with SA+ when } \\
\text { compared with SI+. } \\
\text { - hs-CRP levels in SA+ were } \\
\text { significantly higher than in SA- or } \\
\text { HC. }\end{array}$ & 5.9 & 18.0 \\
\hline $\begin{array}{l}\text { Graça Cantarelli } \\
\text { et al. (2015) }\end{array}$ & SA & 50 & 36 & Affective & After SA & No & Yes & Serum & $\begin{array}{l}- \text { BDNF } \\
\text { - HDL }\end{array}$ & $\begin{array}{l}\text { No significant differences of } \\
\text { BDNF and HDL between SA+ and } \\
\text { SA-. }\end{array}$ & 5.9 & 19.3 \\
\hline $\begin{array}{l}\text { Grassi-Oliveira } \\
\text { et al. (2012) }\end{array}$ & SI & 18 & 14 & MDD & $\begin{array}{l}\text { Interview, } \\
\text { Self-report }\end{array}$ & Yes & No & Plasma & $\begin{array}{l}\text { - CCL2 } \\
\text { - RANTES } \\
\text { - CCL11 }\end{array}$ & $\begin{array}{l}\text { Lower CCL2 and RANTES levels } \\
\text { were detected in SI+, compared } \\
\text { with SA- and HC. }\end{array}$ & 4.8 & 12.0 \\
\hline $\begin{array}{l}\text { Grudet et al. } \\
\text { (2014) }\end{array}$ & SA & 59 & 16 & Mixed & After SA & No & Yes & Serum & - Vitamin D & $\begin{array}{l}\text { Vitamin D levels in SA+ were } \\
\text { significantly lower than in SA- or } \\
\text { HC. }\end{array}$ & 4.1 & 21 \\
\hline $\begin{array}{l}\text { Gundogdu } \\
\text { Meydaneri } \\
\text { et al. (2018) }\end{array}$ & SA & 27 & 26 & MDD & After SA & Partly & No & Blood & $\begin{array}{l}\text { - WBC } \\
\text { - NPs } \\
\text { - Lymphs } \\
\text { - Monocytes } \\
\text { - NLR }\end{array}$ & $\begin{array}{l}\text { No significant differences of those } \\
\text { biomarkers between groups. }\end{array}$ & 4.5 & 17.5 \\
\hline
\end{tabular}




\begin{tabular}{|c|c|c|c|c|c|c|c|c|c|c|c|c|}
\hline $\begin{array}{l}\text { Janelidze et al. } \\
\text { (2015) }\end{array}$ & SA & 46 & 13 & Mixed & After SA & No & Yes & Plasma & IL-8 & $\begin{array}{l}\text { No significant differences of IL-8 } \\
\text { between SA+ and HC. }\end{array}$ & 6.3 & 17.3 \\
\hline $\begin{array}{l}\text { Khan et al. } \\
(2019)\end{array}$ & SI & 28 & 58 & MDD & Interview & Yes & Yes & Serum & - BDNF & $\begin{array}{l}\text { BDNF levels in SI+ were } \\
\text { significantly lower than in SI-. }\end{array}$ & 9.4 & 9.0 \\
\hline $\begin{array}{l}\text { Kim et al (2006) } \\
\text { [a] }\end{array}$ & SA & 39 & 57 & MDD & After SA & Partly & Yes & Plasma & NOx & $\begin{array}{l}\text { NOx levels in SA+ were } \\
\text { significantly higher than in SA- or } \\
\text { HC. }\end{array}$ & 8.4 & 16.0 \\
\hline $\begin{array}{l}\text { Kim et al. } \\
\text { (2007) [b] }\end{array}$ & SA & 32 & 31 & MDD & After SA & Partly & No & Plasma & - BDNF & $\begin{array}{l}\text { BDNF levels in SA+ were } \\
\text { significantly lower than in SA- or } \\
\text { HC. }\end{array}$ & 4.7 & 17.5 \\
\hline $\begin{array}{l}\text { Kim et al. } \\
(2014)[c]\end{array}$ & SI & 93 & 639 & Not Applicable & Interview & No & Yes & Serum & $-\mathrm{HDL}$ & $\begin{array}{l}\text { - No significant differences of HDL } \\
\text { between groups. }\end{array}$ & 5.3 & 21.5 \\
\hline $\begin{array}{l}\text { Kurosawa et al. } \\
\text { (2018) }\end{array}$ & SA & 33 & 146 & Mixed & After SA & No & No & Plasma & \begin{tabular}{|l|} 
- AA \\
- EPA \\
- DHA \\
\end{tabular} & $\begin{array}{l}\text { EPA levels were negatively } \\
\text { associated with SA+, whilst DHA } \\
\text { levels were positively associated. }\end{array}$ & 4.4 & 19.5 \\
\hline $\begin{array}{l}\text { Lee at al. (2006) } \\
\text { [a] }\end{array}$ & SA & 53 & 67 & Mixed & After SA & Partly & Yes & Plasma & $-\mathrm{NOx}$ & $\begin{array}{l}\text { NOx levels in SA+ were } \\
\text { significantly higher than in SA- or } \\
\text { HC. }\end{array}$ & 8.1 & 15.5 \\
\hline $\begin{array}{l}\text { Lee et al. (2007) } \\
\text { [b] }\end{array}$ & SA & 28 & 72 & MDD & After SA & Partly & Yes & Plasma & BDNF & $\begin{array}{l}\text { BDNF levels in SA+ were } \\
\text { significantly lower than in SA-. }\end{array}$ & 9.7 & 10.5 \\
\hline Liu et al. (2020) & SI & 24 & 61 & MDD & Self-report & Yes & No & Serum & $\begin{array}{l}\text { - IL-1 } \beta \\
\text { - IL-6 } \\
\text { - IFN- } \gamma \\
\text { - TNF- } \alpha \\
\text { - Chemokines } \\
\text { (i.e., CCL8, IL- } \\
\text { 8, etc.) }\end{array}$ & $\begin{array}{l}\text { CCL8 levels in SI+ were } \\
\text { significantly higher than in SI- or } \\
\text { HC. } \\
\text { No further significant finding was } \\
\text { observed between SI+ and SI- or } \\
\text { HC. }\end{array}$ & 7.0 & 9.8 \\
\hline $\begin{array}{l}\text { Loas et al. } \\
\text { (2016) }\end{array}$ & SA & 41 & 81 & Mixed & After SA & No & Yes & Serum & - hs-CRP & $\begin{array}{l}\text { - hs-CRP levels in SA+ were } \\
\text { significantly higher than in SA-. }\end{array}$ & 3.0 & 19.0 \\
\hline Ma et al. (2020) & SA & 235 & 1372 & MDD & Interview & Partly & Yes & Plasma & $-\mathrm{HDL}$ & $\begin{array}{l}\text { - HDL levels in SA+ were } \\
\text { significantly lower than in SA-. }\end{array}$ & $\begin{array}{c}5.9 \\
\end{array}$ & 17.5 \\
\hline $\begin{array}{l}\text { Maes et al. } \\
\text { (1989) }\end{array}$ & SI & 17 & 17 & MDD & Interview & Partly & Yes & Blood & \begin{tabular}{|l|}
- TRP \\
- TRP/CAA \\
\end{tabular} & $\begin{array}{l}\text { No significant differences between } \\
\text { SI+ and SI- in TRP or TRP/CAA. }\end{array}$ & 4.7 & 13.5 \\
\hline $\begin{array}{l}\text { Mensi et al. } \\
\text { (2016) }\end{array}$ & SA & 15 & 71 & Other & After SA & Partly & Yes & Serum & $-\mathrm{HDL}$ & $\begin{array}{l}\text { - HDL had no significant association } \\
\text { with SA in schizophrenia patients. }\end{array}$ & 4.1 & 22.5 \\
\hline $\begin{array}{l}\text { Mohamed et al. } \\
(2020)\end{array}$ & SI & 24 & 74 & MDD & Self-report & Partly & No & Serum & - hs-CRP & $\begin{array}{l}\text { - hs-CRP levels in SI+ were } \\
\text { significantly higher than in SI-. }\end{array}$ & 4.1 & 18.5 \\
\hline $\begin{array}{l}\text { Nässberger \& } \\
\text { Träskman- } \\
\text { Bendz(1993) }\end{array}$ & SA & 30 & 25 & Mixed & After SA & Partly & No & Plasma & - sIL-2R & $\begin{array}{l}\text { - sIL-2R levels in SA+ were } \\
\text { significantly higher than in HC. }\end{array}$ & 4.5 & 21.5 \\
\hline $\begin{array}{l}\text { O'Donovan } \\
\text { et al. (2013) }\end{array}$ & SI & 29 & 48 & MDD & Interview & Partly & Yes & Plasma & $\begin{array}{l}\text { - hs-CRP } \\
\text { - IL-6 } \\
\text { - IL-10 } \\
\text { - TNF- } \alpha \\
\end{array}$ & $\begin{array}{l}\text { IL-6 and hs-CRP levels in SI+ were } \\
\text { significantly higher than in HC. }\end{array}$ & 6.0 & 21.0 \\
\hline Oh et al. (2020) & SA & 405 & 3584 & Affective & Interview & No & No & Blood & $\begin{array}{l}\text { - hs-CRP } \\
\text { - ESR } \\
\text { - WBC } \\
\text { - Vitamin D }\end{array}$ & $\begin{array}{l}\text { - hs-CRP and ESR levels in SA+ } \\
\text { were significantly higher than in } \\
\text { SA-. }\end{array}$ & 1.6 & 25 \\
\hline $\begin{array}{l}\text { Oshnokhah } \\
\text { et al. (2020) }\end{array}$ & SA & 50 & 40 & $\begin{array}{l}\text { Excluded } \\
\text { psychiatric } \\
\text { disorders } \\
\text { group }\end{array}$ & After SA & $\begin{array}{l}\text { Yes } \\
\end{array}$ & Yes & Serum & $\begin{array}{l}- \text { MDA } \\
\text { - NOx } \\
- \text { TAC }\end{array}$ & $\begin{array}{l}\text { - MDA and TAC levels were } \\
\text { substantially lower in SA+ than in } \\
\text { HC, whereas NOx levels were } \\
\text { significantly higher. }\end{array}$ & 6.9 & 14.0 \\
\hline $\begin{array}{l}\text { Özer et al. } \\
\text { (2004) }\end{array}$ & SI & 10 & 17 & Other & Interview & Partly & Yes & Serum & HDL & $\begin{array}{l}\text { - No significant association between } \\
\text { HDL and SI+ in panic patients. }\end{array}$ & 5.9 & 14.0 \\
\hline $\begin{array}{l}\text { Park et al. } \\
\text { (2014) }\end{array}$ & SI & 18 & 56 & MDD & $\begin{array}{l}\text { Interview, } \\
\text { Self-report }\end{array}$ & No & Yes & Serum & HDL & $\begin{array}{l}\text { No significant differences of HDL } \\
\text { between groups. }\end{array}$ & 5.0 & 18.5 \\
\hline
\end{tabular}




\begin{tabular}{|c|c|c|c|c|c|c|c|c|c|c|c|c|}
\hline $\begin{array}{l}\text { Pasyk et al. } \\
\text { (2020) }\end{array}$ & SA & 117 & 176 & Mixed & After SA & No & Yes & Serum & - BDNF & $\begin{array}{l}\text { - BDNF levels were shown to be } \\
\text { significantly associated with self- } \\
\text { reported impulsivity scores, but not } \\
\text { with SA. }\end{array}$ & 6.6 & 19.0 \\
\hline $\begin{array}{l}\text { Peng et al. } \\
\text { (2018) }\end{array}$ & SA & 69 & 202 & MDD & After SA & Partly & Yes & Serum & \begin{tabular}{|l|} 
- hs-CRP \\
- HDL \\
- Albumin \\
\end{tabular} & $\begin{array}{l}\text { No significant differences among } \\
\text { those biomarkers between SA+ and } \\
\text { SA-. }\end{array}$ & 8.8 & 14.0 \\
\hline $\begin{array}{l}\text { Pinheiro et al. } \\
\text { (2012) }\end{array}$ & SI & 14 & 176 & Affective & Interview & No & Yes & Serum & - BDNF & $\begin{array}{l}\text { BDNF levels were significant } \\
\text { lower in SIt than in SI-. }\end{array}$ & 7.2 & 21.5 \\
\hline $\begin{array}{l}\text { Priya et al. } \\
\text { (2016) }\end{array}$ & SA & 42 & 42 & Not Applicable & After SA & No & No & Serum & $\begin{array}{l}\text { - BDNF } \\
\text { - hs-CRP } \\
\text { - IL-6 }\end{array}$ & $\begin{array}{l}\text { BDNF levels were substantially } \\
\text { lower in SA+ than in HC, whereas } \\
\text { hs-CRP and IL-6 levels were } \\
\text { significantly higher. } \\
\text { - After adjusting for confounder } \\
\text { factors, linear regression indicated } \\
\text { hs-CRP as a predictor of suicide } \\
\text { risk. }\end{array}$ & 5.6 & 18.0 \\
\hline $\begin{array}{l}\text { Rasheed et al. } \\
\text { (2019) }\end{array}$ & SA & 22 & 34 & MDD & After SA & Partly & Yes & Plasma & $\begin{array}{l}-\mathrm{HDL} \\
-\mathrm{IL}-1 \beta \\
-\mathrm{TNF}-\alpha\end{array}$ & $\begin{array}{l}\text { TNF- levels were significantly } \\
\text { higher in SA+ than in SA- or HC, } \\
\text { while there were no significant } \\
\text { differences in IL-6 or HDL levels } \\
\text { between the groups. }\end{array}$ & 6.0 & 12.0 \\
\hline $\begin{array}{l}\text { Roy \& Roy } \\
\text { (2006) }\end{array}$ & SI & 61 & 397 & Affective & Self-report & No & No & Serum & $\mathrm{HDL}$ & $\begin{array}{l}\text { No significant association between } \\
\text { HDL and SI+ in depressive patients } \\
\text { with Type I Diabetes. }\end{array}$ & 2.8 & 24.5 \\
\hline $\begin{array}{l}\text { Ruljancic et al. } \\
\text { (2013) }\end{array}$ & SA & 79 & 89 & MDD & After SA & No & No & Serum & - Albumin & $\begin{array}{l}\text { Albumin levels were significantly } \\
\text { lower in SA+ than in SA- or HC. }\end{array}$ & 5.3 & 18.4 \\
\hline $\begin{array}{l}\text { Segoviano- } \\
\text { Mendoza et al. } \\
\text { (2018) }\end{array}$ & SA & 59 & 204 & MDD & After SA & Partly & Yes & Serum & HDL & $\begin{array}{l}\text { No significant differences of HDL } \\
\text { between groups. }\end{array}$ & 7.5 & 16.5 \\
\hline Si et al. (2020) & SI & 241 & 441 & Not Applicable & Self-report & No & Yes & Serum & HDL & $\begin{array}{l}\text { No significant differences of HDL } \\
\text { between SI+ and SI-. } \\
\text { Females with SI had higher HDL } \\
\text { concentrations than males with SI, } \\
\text { but females and males without SI } \\
\text { revealed no significant differences. }\end{array}$ & 4.0 & 20.5 \\
\hline $\begin{array}{l}\text { Sowa-Kucma et } \\
\text { al. (2018) }\end{array}$ & SI & 93 & 95 & Affective & Interview & Partly & Yes & Serum & $\begin{array}{l}\text { - zCMI+TBARS } \\
\text { - sIL-1RA } \\
\text { - sIL-2R } \\
\text { - sIL-6R } \\
\text { - IL-1 } \alpha \\
\text { - TBARS } \\
\text { - sTNFR60 } \\
\text { - sTNFR80 } \\
\end{array}$ & $\begin{array}{l}\text { - Increased TBARS was associated } \\
\text { with SI. } \\
\text { - In SI, there were no significant } \\
\text { differences in other biomarkers } \\
\text { across groups. }\end{array}$ & 9.3 & 9.0 \\
\hline Su et al. (2019) & SI & 143 & 219 & Affective & Self-report & No & No & Serum & - HDL & $\begin{array}{l}\text { HDL levels were significant higher } \\
\text { in SI+ than in SI-. }\end{array}$ & 5.3 & 20.5 \\
\hline $\begin{array}{l}\text { Velasco et al. } \\
\text { (2020) }\end{array}$ & SA & 126 & 136 & MDD & Interview & Yes & Yes & Blood & $\begin{array}{l}\text { - Leukocytes } \\
\text { - Lymphs } \\
\text { - Monocytes } \\
\text { - NPs } \\
\text { - NLR } \\
\text { - MLR } \\
\end{array}$ & $\begin{array}{l}\text { Lymphs and NLR were significant } \\
\text { differences between SA+ and SA-, } \\
\text { whilst there were no significant } \\
\text { differences in other biomarkers } \\
\text { across groups. }\end{array}$ & 5.5 & 16.0 \\
\hline $\begin{array}{l}\text { Verma et al. } \\
(1999)\end{array}$ & SA & 40 & 40 & Mixed & After SA & No & Yes & Serum & - HDL & $\begin{array}{l}\text { HDL levels revealed no significant } \\
\text { differences between SA+ and SA-. }\end{array}$ & 5.0 & 12.5 \\
\hline $\begin{array}{l}\text { Yagci \& Avci } \\
\text { (2021) }\end{array}$ & SA & 40 & 41 & Mixed & After SA & Partly & Yes & Blood & $\begin{array}{l}\text { - CRP } \\
\text { - Leukocytes } \\
\text { - NLR } \\
\end{array}$ & $\begin{array}{l}\text { CRP, leukocytes, and NLR } \\
\text { concentrations were significant } \\
\text { higher in SA+ than in HC. }\end{array}$ & 3.8 & 12.5 \\
\hline
\end{tabular}




\section{Abbreviations:}

AA: Arachidonic acid (omega-6 fatty acid)

BDNF: Brain-derived neurotrophic factor

CCL: The $\mathrm{C}-\mathrm{C}$ motif chemokine ligand

CRP: C-reactive protein

DHA: Docosahexaenoic acid (omega-3 fatty acid)

EPA: Eicosapentaenoic acid (omega-3 fatty acid)

HDL-c: High-density lipoprotein cholesterol

hsCRP: The high-sensitivity C-reactive protein

IL: Interleukin

IFN: Interferon

KYN: Kynurenine

Lymphs: Lymphocytes

MDA: Malondialdehyde

MLR: Monocyte to lymphocyte ratio

NLR: Neutrophil-to-lymphocyte ratio

NOx: Nitric oxide metabolites

NPs: Neutrophils

PA: Picolinic acid

QA: Quinolinic acid

RANTES: Regulated on Activation, Normal T Cell Expressed and Secreted

SA: Suicide attempts

SI: Suicide ideation

sIL2R: Soluble Interleukin 2 Receptor

sIL6R: Soluble Interleukin 6 Receptor

STNF- $\alpha$ R1: Soluble tumor necrosis factor alpha receptor 1

TAC: Total antioxidant capacity

TBARS: Thiobarbituric acid reactive substances

TNF: Tumor necrosis factor

TNFR: Tumor necrosis factor receptors

TRYCATs: The tryptophan catabolites

TRP: Tryptophans 
ESF 1 Table 5. Excluded studies.

\begin{tabular}{|l|l|l|}
\hline \multicolumn{1}{|c|}{ Authors, year } & \multicolumn{1}{|c|}{ Reason why excluded } & \multicolumn{1}{c|}{ Key findings } \\
\hline Dickerson et al., 2017 & Graph format. & $\begin{array}{l}\text { There was a significantly higher level of CRP in the patients with history of suicide } \\
\text { attempts more than 1 month (coefficient=0.87, 95\% CI 0.25, 1.50, p=0.006) compared } \\
\text { with the control group but not in the other two psychiatric groups (p > 0.05), including } \\
\text { patients with history of suicide attempts in 1 month and without history of suicide } \\
\text { attempts, when adjusting for age, gender, race, smoking status, and BMI }\end{array}$ \\
\hline Jha et al., 2020 & $\begin{array}{l}\text { Combined case group with suicide } \\
\text { attempts and suicidal ideation. }\end{array}$ & $\begin{array}{l}\text { After adjustment, only IL-4 revealed significantly differences between healthy control } \\
\text { (n=39), those at risk of MDD group (n=33), and those at risk of MDD with recent } \\
\text { suicide attempts or suicidal ideation group (n=37), whereas the other cytokines and } \\
\text { chemokines did not. Plasma IL-4 levels of recent suicide group had lower than healthy } \\
\text { controls and at risk of MDD group. }\end{array}$ \\
\hline Lauterbach et al., 2006 & Correlation coefficient. & $\begin{array}{l}\text { There is a modest correlation between suicidal ideation and low plasma } \\
\text { trytophan/amino acid ratio (r=0.39, p=0.042). }\end{array}$ \\
\hline Melhem et al., 2017 & $\begin{array}{l}\text { Logarithmic trasformation. The } \\
\text { authors did dot provide mean (SD) } \\
\text { values upon request. }\end{array}$ & $\begin{array}{l}\text { Patients with suicide attempts showed significantly higher CRP [95\% CI (0.15, 1.84), p } \\
=0.02 \text { compared to patients with suicidal ideation and healthy controls. }\end{array}$ \\
\hline Roggenbach et al., 2007 & $\begin{array}{l}\text { Combined case group with suicide } \\
\text { attempts and suicidal ideation. }\end{array}$ & $\begin{array}{l}\text { There is no significant different between depression patients with suicide group and } \\
\text { healthy control in plasma tryptophan. }\end{array}$ \\
\hline
\end{tabular}

a. Dickerson F, Adamos M, Katsafanas E, Khushalani S, Origoni A, Savage C et al. The association between immune markers and recent suicide attempts in patients with serious mental illness: A pilot study. Psychiatry Res 2017; 255: 8-12.

b. Jha MK, Cai L, Minhajuddin A, Fatt CC, Furman JL, Gadad BS et al. Dysfunctional adaptive immune response in adolescents and young adults with suicide behavior. Psychoneuroendocrinology 2020; 111: 104487.

c. Lauterbach E, Brunner J, Hawellek B, Lewitzka U, Ising M, Bondy B et al. Platelet 5-HT2A receptor binding and tryptophan availability in depression are not associated with recent history of suicide attempts but with personality traits characteristic for suicidal behavior. Journal of Affective Disorders 2006; 91(1): 57-62.

d. Melhem NM, Munroe S, Marsland A, Gray K, Brent D, Porta G et al. Blunted HPA axis activity prior to suicide attempt and increased inflammation in attempters. Psychoneuroendocrinology 2017; 77: 284-294.

e. Roggenbach J, Müller-Oerlinghausen B, Franke L, Uebelhack R, Blank S, Ahrens B. Peripheral serotonergic markers in acutely suicidal patients. 1. Comparison of serotonergic platelet measures between suicidal individuals, nonsuicidal patients with major depression and healthy subjects. Journal of Neural Transmission 2007 ; 114(4): 479-487. 


\section{Electronic Supplementary Information File (ESF) 2}

Activated immune, oxidative and nitrosative stress pathways are strongly associated with suicidal attempts and less with suicidal ideation: a meta-analysis and meta-regression.

Running title: immune activation in suicidal behaviors

Asara Vasupanrajit, M.Sc. ${ }^{a}$; Ketsupar Jirakran, M.Sc. ${ }^{\text {a,b }}$, Chavit Tunvirachaisakul, M.D., Ph.D. ${ }^{\text {a, c }}$; Michael Maes, M.D., Ph.D. ${ }^{\text {a, c, d, e }}$

${ }^{a}$ Department of Psychiatry, Faculty of Medicine, Chulalongkorn University, Bangkok, Thailand.

${ }^{\mathrm{b}}$ Maximizing Thai Children's Developmental Potential Research Unit, Department of Pediatrics, Faculty of Medicine, Chulalongkorn University, Bangkok, Thailand.

c Cognitive Impairment and Dementia Research Unit, Department of Psychiatry, Faculty of Medicine, Chulalongkorn University, Bangkok, Thailand.

${ }^{\mathrm{d}}$ IMPACT Strategies Research Center, Deakin University, Geelong, Australia.

${ }^{\mathrm{e}}$ Department of Psychiatry, Medical University of Plovdiv, Plovdiv, Bulgaria. 
ESF 2 Table 1. Results of other subgroup analyses performed on IO\&NS profile.

\begin{tabular}{|c|c|c|c|c|c|c|c|c|c|c|c|c|}
\hline Comparison & $\begin{array}{c}\mathbf{n} \\
\text { studies }\end{array}$ & subgroups & SMD & $95 \% \mathrm{CI}$ & $\mathbf{z}$ & $\mathbf{p}$ & $\mathbf{Q}$ & df & $\mathbf{p}$ & $\begin{array}{c}\mathbf{I}^{2} \\
(\%)\end{array}$ & $\overline{\tau^{2}}$ & $\mathbf{T}$ \\
\hline \multicolumn{13}{|c|}{ Subgroups by psychiatric groups } \\
\hline \multirow{4}{*}{$\begin{array}{l}\text { SB versus Controls } \\
\left(\chi^{2}=8.563 ; \mathrm{df}=3 ; \mathrm{p}=0.036\right)\end{array}$} & 29 & MDD & 0.370 & $0.195 ; 0.546$ & 4.135 & $<0.001$ & 141.577 & 28 & $<0.001$ & 80.223 & 0.168 & 0.410 \\
\hline & 15 & MIX & 0.372 & $0.201 ; 0.543$ & 4.267 & $<0.001$ & 57.569 & 14 & $<0.001$ & 75.681 & 0.075 & 0.274 \\
\hline & 9 & Affective & 0.049 & $-0.156 ; 0.254$ & 0.470 & 0.639 & 30.696 & 8 & $<0.001$ & 73.938 & 0.063 & 0.251 \\
\hline & 6 & OTHER & 0.140 & $-0.067 ; 0.346$ & 1.326 & 0.185 & 3.577 & 5 & 0.612 & 0.000 & 0.000 & 0.000 \\
\hline \multicolumn{13}{|c|}{ Subgroups by participants groups } \\
\hline \multirow{2}{*}{$\begin{array}{l}\text { SB versus Controls } \\
\left(\chi^{2}=8.147 ; \mathrm{df}=1 ; \mathrm{p}=0.004\right)\end{array}$} & 33 & In-patient & 0.442 & $0.264 ; 0.620$ & 4.862 & $<0.001$ & 203.090 & 32 & $<0.001$ & 84.243 & 0.215 & 0.464 \\
\hline & 18 & Out-patient & 0.128 & $0.007 ; 0.249$ & 2.080 & 0.038 & 37.804 & 17 & 0.003 & 55.031 & 0.027 & 0.165 \\
\hline \multirow{2}{*}{$\begin{array}{l}\text { SA versus Controls } \\
\left(\chi^{2}=5.770 ; \mathrm{df}=1 ; \mathrm{p}=0.016\right)\end{array}$} & 26 & In-patient & 0.505 & $0.312 ; 0.698$ & 5.126 & $<0.001$ & 137.711 & 25 & $<0.001$ & 81.846 & 0.193 & 0.439 \\
\hline & 5 & Out-patient & 0.151 & $-0.064 ; 0.366$ & 1.375 & 0.169 & 12.688 & 4 & 0.013 & 68.474 & 0.031 & 0.177 \\
\hline \multicolumn{13}{|l|}{ Subgroups by medium } \\
\hline \multirow{3}{*}{$\begin{array}{l}\text { SB versus Controls } \\
\left(\chi^{2}=4.677 ; \mathrm{df}=2 ; \mathrm{p}=0.096\right)\end{array}$} & 7 & Blood & 0.229 & $0.066 ; 0.391$ & 2.759 & 0.006 & 10.229 & 6 & 0.115 & 41.341 & 0.018 & 0.132 \\
\hline & 19 & Plasma & 0.509 & $0.275 ; 0.742$ & 4.270 & $<0.001$ & 123.125 & 18 & $<0.001$ & 85.381 & 0.199 & 0.446 \\
\hline & 39 & Serum & 0.232 & $0.117 ; 0.347$ & 3.958 & $<0.001$ & 147.864 & 38 & $<0.001$ & 74.301 & 0.089 & 0.298 \\
\hline \multicolumn{13}{|c|}{ Subgroups by the assessment of suicide behaviors } \\
\hline \multirow{3}{*}{$\begin{array}{l}\text { SB versus Controls } \\
\left(\chi^{2}=8.479 ; \mathrm{df}=2 ; \mathrm{p}=0.014\right)\end{array}$} & 32 & Suicidal act & 0.456 & $0.291 ; 0.622$ & 5.409 & $<0.001$ & 155.948 & 31 & $<0.001$ & 80.122 & 0.168 & 0.410 \\
\hline & 18 & Interview & 0.173 & $0.070 ; 0.275$ & 3.304 & 0.001 & 28.494 & 17 & 0.039 & 40.338 & 0.016 & 0.126 \\
\hline & 11 & Self-report & 0.184 & $-0.031 ; 0.400$ & 1.676 & 0.094 & 58.554 & 10 & $<0.001$ & 82.922 & 0.096 & 0.310 \\
\hline \multirow{2}{*}{$\begin{array}{l}\text { SA versus Controls } \\
\left(\chi^{2}=7.102 ; \mathrm{df}=1 ; \mathrm{p}=0.008\right)\end{array}$} & 32 & Suicidal act & 0.456 & $0.291 ; 0.622$ & 5.409 & $<0.001$ & 155.948 & 31 & $<0.001$ & 80.122 & 0.168 & 0.410 \\
\hline & 5 & Interview & 0.120 & $-0.064 ; 0.304$ & 1.277 & 0.201 & 13.129 & 4 & 0.011 & 69.533 & 0.026 & 0.161 \\
\hline
\end{tabular}




\begin{tabular}{|c|c|c|c|c|c|c|c|c|c|c|c|c|}
\hline \multirow{2}{*}{$\begin{array}{l}\text { SI versus Controls } \\
\left(\chi^{2}=0.015 ; \mathrm{df}=1 ; \mathrm{p}=0.902\right)\end{array}$} & 13 & Interview & 0.200 & $0.069 ; 0.331$ & 3.003 & 0.003 & 15.362 & 12 & 0.222 & 21.886 & 0.012 & 0.110 \\
\hline & 11 & Self-report & 0.184 & $-0.031 ; 0.400$ & 1.676 & 0.094 & 58.554 & 10 & $<0.001$ & 82.922 & 0.096 & 0.310 \\
\hline
\end{tabular}

SMD: standardized mean difference, $95 \% \mathrm{CI}$ : $95 \%$ confidence intervals

IO\&NS: immune-inflammatory and oxidative and nitrosative stress

SB: suicide behaviors

SA: suicide attempts

SI: suicidal ideation

We used the prespecified subgroups as the units of analysis. Thus, patients with suicide behaviors were first compared with controls. Second, we compared a) $\mathrm{SA}+$ versus controls); and b) SI+ versus controls. 
ESF 2 Table 2. Results on publication bias.

\begin{tabular}{|l|c|c|c|c|c|c|c|}
\hline $\begin{array}{c}\text { Outcome } \\
\text { feature sets }\end{array}$ & Fail safe n & Z Kendall's $\boldsymbol{c}$ & $\begin{array}{c}\text { p-value } \\
(\mathbf{1}-\text {-tailed })\end{array}$ & $\begin{array}{c}\text { Egger's t test } \\
\text { (df) }\end{array}$ & $\begin{array}{c}\text { p-value } \\
\text { (1-tailed) }\end{array}$ & $\begin{array}{c}\text { Missing studies } \\
\text { (side) }\end{array}$ & $\begin{array}{c}\text { Adjusted SMD } \\
(\mathbf{9 5 \%} \% \mathbf{C I})\end{array}$ \\
\hline IO\&NS & 1829 & 1.44 & 0.075 & $2.50(57)$ & 0.008 & $6(\mathrm{R})$ & $0.371(0.263 ; 0.479)$ \\
\hline IRS & 1304 & 0.73 & 0.233 & $2.67(31)$ & 0.006 & $5(\mathrm{R})$ & $0.551(0.403 ; 0.710)$ \\
\hline Inflammation & 828 & 1.06 & 0.145 & $2.07(24)$ & 0.025 & $3(\mathrm{R})$ & $0.556(0.376 ; 0.737)$ \\
\hline CRP & 529 & 2.57 & 0.005 & $3.24(13)$ & 0.003 & $2(\mathrm{R})$ & $0.692(0.428 ; 0.956)$ \\
\hline Neurotoxicity & 776 & 0.13 & 0.448 & $1.93(27)$ & 0.032 & $4(\mathrm{R})$ & $0.490(0.335 ; 0.645)$ \\
\hline ANTIOXPRO & 319 & 0.72 & 0.235 & $1.03(38)$ & 0.154 & $4(\mathrm{R})$ & $0.249(0.124 ; 0.374)$ \\
\hline BDNF & 110 & 0.89 & 0.186 & $1.99(8)$ & 0.041 & 0 & - \\
\hline
\end{tabular}

SMD: standardized mean difference, $95 \%$ CI: $95 \%$ confidence intervals IO\&NS: immune-inflammatory and oxidative and nitrosative stress

IRS: immune-inflammatory response system

ANTIOXPRO: protection via antioxidants and neurotrophic products.

CRP: C-reactive protein

BDNF: Brain-derived neurotrophic factor 


\section{IO\&NS profile in SASI}

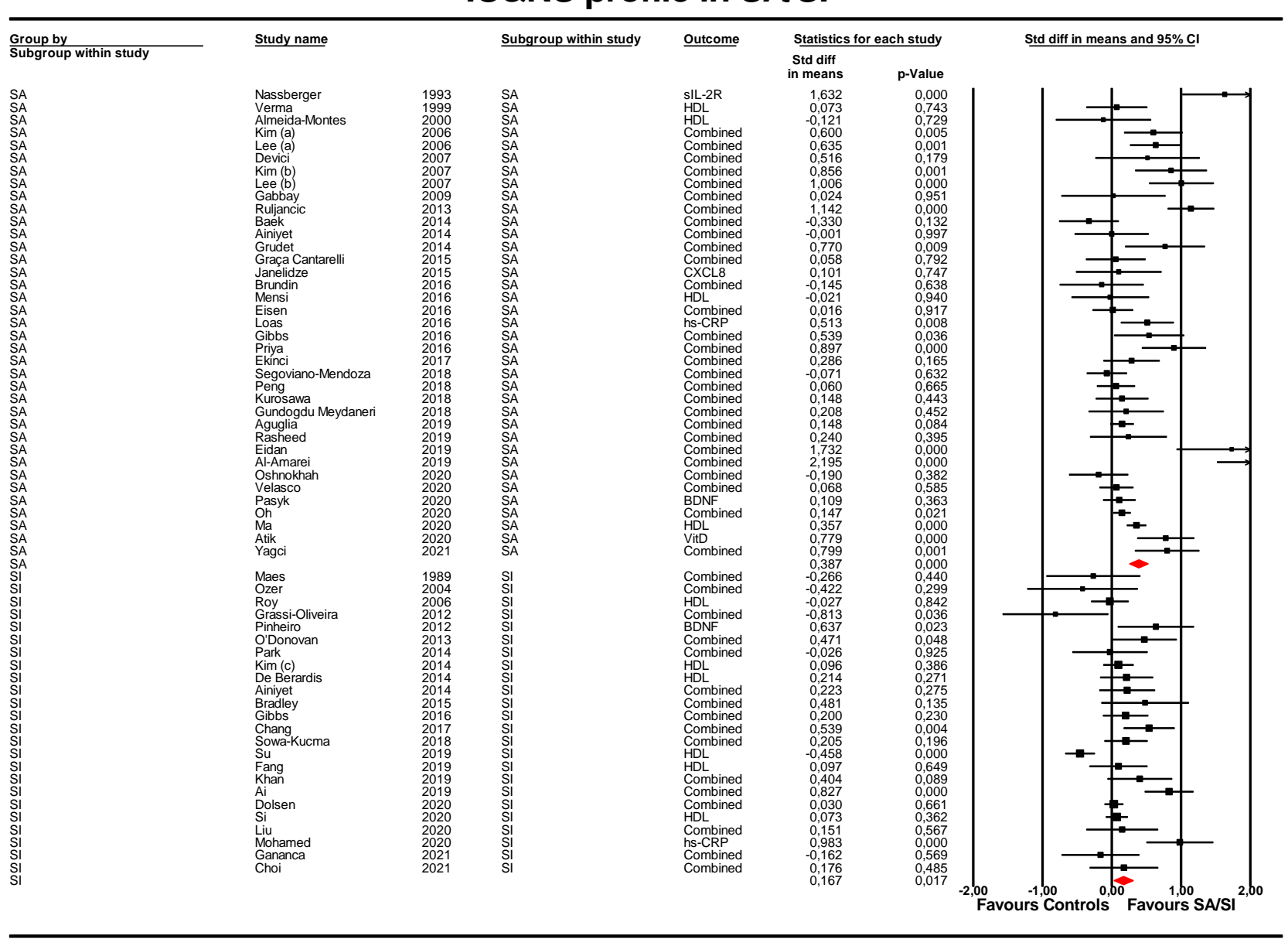

Vasupanrajit et al.

ESF 2 Figure 1. Forest plot with results of subgroup analysis performed on 61 suicide attempts (SA) or suicidal ideation (SI) studies reporting immune-inflammatory and oxidative \& nitrosative stress (IO\&NS) biomarkers. 


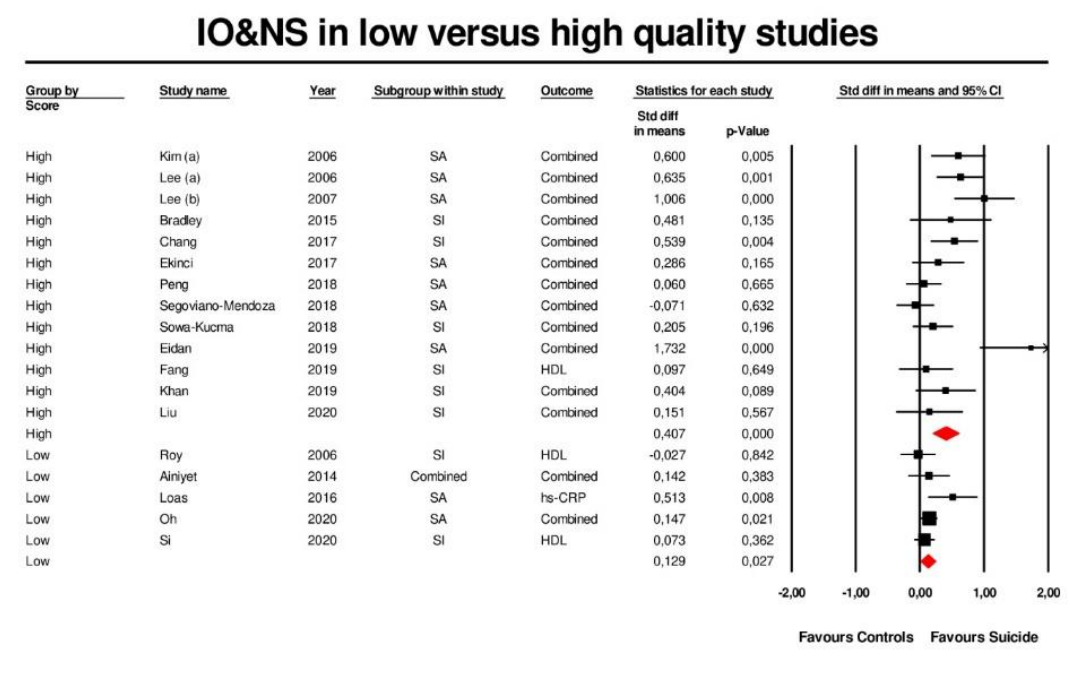

Vasuparrajit t tal.

ESF 2 Figure 2. Forest plot with results of meta-analysis performed on 13 high- and 5 low-quality studies reporting immuneinflammatory and oxidative \& nitrosative stress (IO\&NS) biomarkers when comparing suicide behaviors to controls. 